\title{
SOIL-RAFT FOUNDATION-STRUCTURE INTERACTION EFFECTS ON SEISMIC PERFORMANCE OF MULTI-STORY MRF BUILDINGS
}

\author{
Shehata E. ABDEL RAHEEM ${ }^{\mathrm{a}, \mathrm{b}}$, Mohamed M. AHMED ${ }^{\mathrm{b}}$, Tarek M. A. ALAZRAK ${ }^{\mathrm{c}}$ \\ ${ }^{a}$ Civil Engineering Department, Faculty of Engineering, Taibah University, Madinah 41411, KSA \\ ${ }^{b}$ Civil Engineering Department, Faculty of Engineering, Assiut University, Assiut 71516, Egypt \\ ${ }^{c}$ Faculty of Engineering, Sohag University, Sohag 82524, Egypt
}

Received 29 May 2014; accepted 16 September 2014

\begin{abstract}
Recent studies show that the effects of Soil Structure Interaction (SSI) may be detrimental to the seismic response of structure and neglecting SSI in analysis may lead to un-conservative design. Despite this, the conventional design procedure usually involves assumption of fixity at the base of foundation neglecting the flexibility of the foundation, the compressibility of soil mass and consequently the effect of foundation settlement on further redistribution of bending moment and shear force demands. The effects of SSI are analyzed for typical multi-story building resting on raft foundation. Three methods of analysis are used for seismic demands evaluation of the target moment resistant frame buildings: equivalent static load (ESL); response spectrum (RS) methods and nonlinear time history (TH) analysis with suit of nine time history records. Three-dimensional Finite Element (FE) model is constructed to analyze the effects of different soil conditions and number of stories on the vibration characteristics and seismic response demands of building structures. Numerical results obtained using soil structure interaction model conditions are compared to those corresponding to fixed-base support conditions. The peak responses of story shear, story moment, story displacement, story drift, moments at beam ends, as well as force of inner columns are analyzed.
\end{abstract}

Keywords: soil-structure interaction, seismic design, Egyptian building code, time history, dynamic analysis, moment resistant multi-story building, raft foundation.

\section{Introduction}

Over the past 40 years considerable progress has been made in understanding the nature of earthquakes and how they damage structures, and in improving the seismic performance of the built environment. However, much remains unknown regarding the prevention or mitigation of earthquake damage in worldwide, leaving room for further studies. During past and recent earthquakes, it is realized that the soil-structure interaction (SSI) effects play an important role in determining the behavior of building structures. The seismic excitation experienced can be considered a function of the fault rupture mechanism, travel path effects, local site effects, and SSI effects (Gu 2008). Ir- respective of the structure, the local soil conditions can dramatically influence the earthquake motion from the bedrock level to the ground surface, through their dynamic filtering effects. One example is the 1985 Mexico City earthquake where deep soft soils amplified the ground motion and modified the frequency of ground shaking. Similar behavior was observed during the 1989 Loma Prieta earthquake, in which the sections of the Cypress freeway in Oakland collapsed due to the soil-related motion amplification. The seismic soil structure interaction of multi-story buildings becomes very important after the destruction of recent major earthquake. For the structure founded on the soil, the motion of the base of the structure will be different 
from the case of fixed base (El-Sayed 2005), because of the coupling of the structure-soil system. It is true that taking the soil into account when calculating the seismic response of the structure does complicate the analysis considerably. It also makes it necessary to estimate additional key parameters, which are difficult to determine, such as the properties of the soil.

This study aims to study the soil-structure-interaction for multi-story buildings on raft foundation; evaluate the approach of Egyptian Code seismic provisions for analysis methods during the seismic design of buildings; to discuss the alternative solutions for cases wherein existing provisions do not lead to satisfactory results and to quantify the effect SSI on the structural response so that designers can be aware of the likely impact of their decisions. Time History analysis (TH) has been performed to evaluate Equivalent Static Load (ESL) and the Response Spectrum (RS) analysis methods; a set of time history records has been used. A parametric study with different approaches of analysis methods; design parameters of the underneath soil condition and number of stories is carried out to evaluate on the building vibration characteristics and seismic demands including the fundamental period, total base shear, story displacements, story drifts, moment at beams ends and force of inner columns. The results show that SSI has a significant influence on the seismic response demands.

\section{Egyptian code provisions for seismic loads}

The great losses due to Cairo earthquake on October 1992 (Ms 5.4) were mainly related to the fact that at the time of construction, the buildings were designed to resist only vertical loads and had insufficient lateral resistance. Thus, the columns and beam column connections were found to have inadequate shear capacity, ductility and confinement in plastic hinges (Abdel Raheem et al. 2010, 2014). This earthquake illustrated the vulnerability of the building stock, especially older structures, due to design, detailing, construction and maintenance issues (Khater 1992; Badawi, Mourad 1994; Mourad et al. 2000). So there is an urgent need for assessment of existing buildings in terms of seismic performance and continuously upgrades the seismic codes for design of new buildings. The design of structures for earthquakes became a major demand enforced in the Egyptian design codes that motivated the Ministry of Housing and Buildings to update the Egyptian codes regularly, to take into account the seismic loads into consideration. Since October 1992, a set of Egyptian codes have been released to prevent buildings collapse and/or control major damages of structural elements. Many advances in earthquake engineering have been made from the observation of the performance of real structures that have been subject to a severe earthquake, analytical modeling, including Finite Element Analysis; FEA, has an important role, but its limitations must be recognized. For many engineered structures, satisfactory seismic performance requires careful attention to analysis, design, and detailing and good construction practice. Safety is thus achieved by the successful integration of analysis, design and construction.

Building code restrictive seismic design provisions and building systems type and configuration have remarkable implications on seismic performance of reinforced concrete moment framed structures (Abdel Raheem 2013; Abdel Raheem et al. 2014). The specifications permit the designer to utilize a variety of methods for seismic analysis that range from simple equivalent static analysis to complex nonlinear dynamic analysis (ICBO 1997; AIJ 1999; SEAOC 1999; IBC 2003; EC 2004; ASCE 2005; ECP203: 2004, 2007; ECP-201: 2008). For building structures, it is common practice to utilize a simplified approach, such as equivalent static load. This approach has several shortcomings, which have been accepted due to its simplicity and a lack of alternative practical approaches (Abdel Raheem 2013; Abdel Raheem et al. 2014). Such approach may be regarded as forcebased since the methods primary emphasis is on the forces within the structure. In recent years, there has been a shift of attention away from linear methods of seismic analyses to nonlinear methods which put emphasis on the displacements within the structure. Thus, nonlinear analysis methods that are capable of realistically predicting the deformations imposed by earthquakes on structures are needed. In response to this need, nonlinear static analysis procedures have appeared in national resource documents such as the ATC3-06 report on seismic regulations for buildings (ATC 1978); the ATC-40 report on seismic evaluation and retrofit of concrete buildings (ATC 1996) and the FEMA-356 pre-standard on seismic rehabilitation of buildings (FEMA 2000). Such analysis methods are useful for predicting inelastic displacement capaci- 
ties while simultaneously offering a compromise between the oversimplification of linear static analysis and the inherent complexity of nonlinear dynamic analysis. The latest Egyptian Code for Load and Forces (ECP-201: 2008) and most of the international participating building codes, depends on the traditional approach of equivalent static load method as a main method for evaluating seismic actions on symmetrical buildings (ICBO 1997; AIJ 1999; EC 2004; ECP-201: 2008). For non-symmetrical buildings, the ECP-201 (2008) recommended the response spectrum method to be used for building seismic analysis and design, which considered more accurate method of analysis than the equivalent static load method (Chopra 1995; Paz, Leigh 2003).

Egypt is suffered a numerous of destructive earthquakes as well as Kalabsha earthquake (1981, Ms 5.4) near Aswan city and the High dam, Dahshour earthquake (1992, Ms 5.9) near Cairo city and Aqaba earthquake (1995, Ms 7.2). As the category of earthquake damage includes all the phenomena related to the direct and indirect damages, the Egyptian authorities do a great effort to mitigate the earthquake disasters. The seismicity especially at the zones of high activity is investigated and the soil condition, soil amplification, soil structure interaction, liquefaction and seismic hazard are carried out in particular the urbanized areas. All these parameters are integrated to obtain the Egyptian building code which is valid to construct buildings resist damages and consequently mitigate the earthquake disasters. A prevailing common conclusion of several studies is that SSI could produce significant effects on the seismic response of structures: both beneficial and detrimental effects were reported. Nevertheless, utilization of the findings of these research efforts in national and international design codes and in routine design calculations is still very rare if not absent.

\section{Seismic analysis procedures}

In the preliminary design process, equivalent static seismic forces are used to determine the design internal forces of structural members using linear elastic analyses of structure and, in turn, determine the design member strength demands. Such static seismic forces are simply determined corresponding to the elastic design acceleration spectrum divided by a structural strength reduction factor particularly called: the res- ponse modification factor, $R$ (ECP-201: 2008; ICBO 1997); the structural behavior factor, $q$ (EC 2004); or the structural factor, $D_{s}$ (AIJ 1999). Usually, the elastic design spectrum, which is often related to $5 \%$ or $10 \%$ Probability Of Exceedance (POE) in 50 years, is defined smoothly as a reasonable representation of the seismic action demand on the structure at the site of interest. The adopted strength reduction factor is thus intended to represent an expected inelastic response demand or expected damage level demand of the whole structure, which may be induced during earthquake excitation (Thuat 2014).

\subsection{Equivalent static load (ESL) method}

According to ECP-201 (2008), the seismic base shear force, $F_{b}$, for each horizontal direction in which the building is analyzed, shall be determined using the following expression:

$$
F_{b}=S_{d}\left(T_{1}\right) \times \lambda \times W / g,
$$

where: $S_{d}\left(T_{1}\right)$ is the ordinate of the design spectrum at period $T_{1} ; T_{1}$ is the fundamental period of vibration of the building for lateral motion in the direction considered; $W$ is the total weight of the building, above the foundation level; $g$ is the gravity acceleration; $\lambda$ is the effective modal mass correction factor, the value of which is equal to: $\lambda=0.85$ for $T \leq 2 T_{C}$, and $n>2$ stories, where $n$ number of stories; $T_{c}$ is the upper limit of the period of the constant spectral acceleration branch as shown in Figure 1. The value of the fundamental period of vibration, $T$, determined using the following expression:

$$
T=C_{t} \times H^{3 / 4},
$$

where $C_{t}$ is a factor determined according to the structural system and building material and equal to 0.075 in case of moment-resistant space concrete frame; $H$ is the height of the building $(m)$; from the foundation or from the top of a rigid basement. The ordinate of the design spectrum, $S_{d}\left(T_{1}\right)$, can be determinate from:

$$
s_{d}(T)=\frac{2.5}{R} \times a_{g} \times \gamma \times S\left[\frac{T_{c}}{T}\right] \geq[0.2] \times a_{g} \times \gamma,
$$

where $a_{g}$ is the design ground acceleration for the reference return period; $T_{c}$ is the upper limit of the period of the constant spectral acceleration branch as shown in Figure 1; $S$ is the soil factor. $\gamma$ is the importance factor. $R$ is the reduction factor according the statical system of the structure. The total base shear, $F_{b}$, shall 
be determined by applying horizontal forces $F_{i}$ to each story mass $m_{i}$ and shall be distributed as follows:

$$
F_{i}=\left[\frac{z_{i} \times W_{i}}{\sum_{j=1}^{n} z_{j} \times W_{j}}\right] \times F_{b},
$$

where $F_{i}$ is the horizontal force acting on story $i ; F_{b}$ is the seismic base shear force (Eq. 1); $z_{i}, z_{j}$ are the heights of the masses $m_{i}, m_{j}$ above the foundation level respectively; $W_{i}, W_{j}$ are the weights of masses $m_{i}$, $m_{j} ; n$ is the number of stories above foundation level. Eq. 4 gives linear shear distribution depending on the story height.

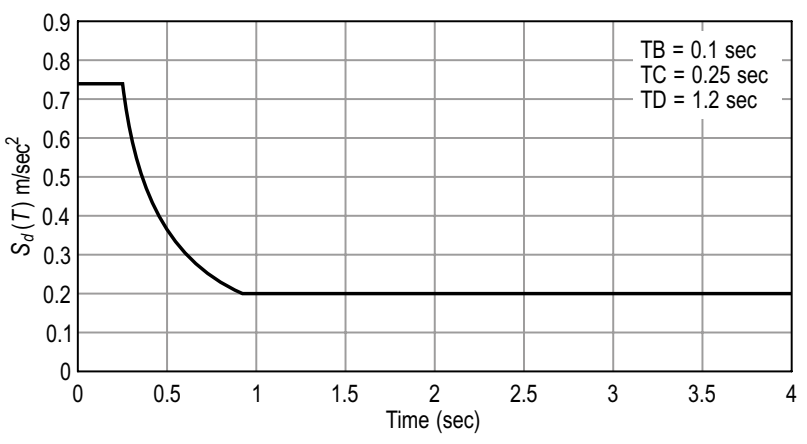

Fig. 1. ECP-201 (2008) design response spectrum

\subsection{Modal response spectrum (RS) method}

The modal response spectrum analysis is applicable for all types of buildings, while the lateral force method of analysis has many restrictions on its use due to the "fear" that it would provide un-conservative results in certain conditions; however, in spite of this disadvantage the method is still widely used due to its ease of application (Crowley, Pinho 2010). Response spectrum analysis includes sufficient modes of vibration to capture participation of at least $90 \%$ of the structure's mass in each of two orthogonal directions (Kunnath, Kalkan 2004). Figure 1 shows the design response spectrum curve for current case of study, it shall be noted that, ECP-201 (2008) includes a damping coefficient in the elastic response spectra equations. Hence, no damping ratio has been used in the analysis of this method. As specified in most design codes, the shape of the target elastic acceleration spectrum is characterized by the seismic intensity expressed in terms of the expected design peak ground acceleration (PGA), $a_{g}$, and the effect of soil ground types expressed in terms of the response spectral periods $T_{b}$ and $T_{c}$. various values of $T_{b}$ and $T_{c}$ were considered corresponding to different soil ground types (from A-type of hard rock to D-type of soft soil).

Many codes (ICBO 1997; AIJ 1999; SEAOC 1999; IBC 2003; EC 2004; ASCE 2005; ECP-203: 2004, 2007; ECP-201: 2008) recognize that the period of vibration from the simplified period-height equation is more realistic, having been directly obtained from the measured periods of vibration of buildings subject to earthquake ground motions (Goel, Chopra 1997; Ghosh, Fanella 2003), but that when higher modes are important (in tall and/or irregular structures) the modal response spectrum method gives a more realistic profile of the lateral forces. Hence, these codes (ECP-201: 2008; NRCC 2005; ASCE 2005) require the designer to check whether the modal base shear force is less than $85 \%$ of the base shear force from the equivalent static force method. If this is the case then the modal forces, but not the drifts, should be multiplied by $0.85 \mathrm{~V} / V_{t}$ where $V$ is the base shear from the lateral force method and $V_{t}$ is the base shear from the required modal combination. Even when higher modes are not important and the designers are allowed to use the linear static method, but they decide to calculate the period of vibration from the Rayleigh method, many codes apply an upper bound to the period of vibration from the Rayleigh method. This is another procedure which is used to safeguard against unrealistically high periods of vibration used in the design to lower the base shear forces (Crowley, Pinho 2010).

The seismic zone considered in this study is zone 1 and the shape of spectrum is type 1 as per Egyptian zoning system with design ground acceleration, $a_{g}$ of $0.1 \mathrm{~g}$ associated with the code reference probability of exceedance of $10 \%$ in $50 \mathrm{yrs}$ as shown in Figure 1. The two models are considered as a residential buildings with importance factor $\gamma=1$. The soil class is considered " $C$ " and a soil factor $S=1.5$. The reduction factor, $\mathrm{R}$, is taken considering the vertical loads and the total base shear are totally resisted by the frame structure without using shear walls or bracings $(\mathrm{R}=5)$. It should be noted that, ECP-201 (2008) recommends that in the application of the Equivalent Static load Method "ESL", the building should meet the criteria for regularity in both plan and elevation, and with calculated structural period T not greater than $2 \mathrm{sec}$ or 4Tc (1 sec for the selected soil class "C"). In ESL method, according to ECP-201 (2008), a total seismic mass including selfweight and floor cover plus $25 \%$ of live load is considered. The base shear is determined as a percentage of 
the total building weight that gives a value of $2.58 \%$ of the total weight of the building in 6-story building and $1.82 \%$ in 12 -story building.

\subsection{Nonlinear time history (TH) method}

Nonlinear time-history analysis is by far the most comprehensive method for seismic analysis. The earthquake record in the form of acceleration time history is input at the base of the structure (Kharade et al. 2013). The response of the structure is computed at each second for the entire duration of an earthquake. This method differs from response spectrum analysis because the effect of "time" is considered. That is, stresses and deformations in the structure at an instant are considered as an initial boundary condition for computation of stresses in the next step. Furthermore, nonlinearities that commonly occur during an earthquake can be included in the time-history analysis. Such nonlinearities cannot be easily incorporated in response spectrum analysis. Unlike the response spectrum method, nonlinear time-history analysis does not assume a specific method for mode combination. Hence, results are realistic and not conservative. Furthermore, this method is equivalent to getting $100 \%$ mass participation using response spectrum analysis. Full mass participation is necessary to generate correct earthquake forces. Usually, only $90-95 \%$ participation is obtained in response spectrum analysis. All types of nonlinearities can be accounted for in this analysis. This could be very important when seismic retrofit involves energy dissipation using yielding of members or plastic hinge rotation. However, this method is very expensive and time consuming to perform. Large amounts of information are generated. Furthermore, input earthquake is never known with certainty. Hence, three to five different histories should be used, further increasing the cost. The equation of motion for a system subjected to earthquake excitations can be written as (Algreane et al. 2011),

$$
[\mathrm{M}] \ddot{u}+[\mathrm{C}] \dot{u}+[\mathrm{K}] u=F(t) .
$$

In which, $M, C$ and $K$ are the mass; damping and stiffness matrices, respectively. $F(t)$ is the seismic excitation and $\ddot{u}, \dot{u}$ and $u$ are accelerations, velocities and displacements time-dependent vectors, respectively. Since the results of the time history depends mainly on the characteristic of the used acceleration time-history records and the shapes of their corresponding elastic response spectra (Kunnath, Kalkan 2004), the reason of using the nonlinear TH method is to verify the results obtained by other code specific analysis procedures (ESL and RS methods) against a time-history record. Nonlinear time-history analysis was performed taking into consideration the P- $\Delta$ and large displacements effect. A constant damping ratio of 0.05 has been taken for RC buildings. The nonlinear time-history analysis is preformed using the direct integration technique considering a time step of 0.005 second. Nonlinear analysis could be used to justify a design that would not satisfy the prescriptive building code requirements. Story drifts and floor accelerations are important indicators of damage to nonstructural components and overall building performance. For nonlinear seismic analyses, a total seismic mass including self-weight and floor cover "Dead Load; $D L$ " plus $25 \%$ of Live Load " $L L$ " $(1.0 D L+0.25 L L)$ is considered (ECP-201: 2008).

\section{Mathematical modeling}

\subsection{Building description}

During the past two decades, the building environment in Egypt had extensively utilized medium rise RC buildings having twelve stories, the maximum height allowed by the local authorities in most districts. These building are built with different configurations and structural systems having varying stiffness parameters that may have great influence on their seismic behavior. Two Samples for typical buildings with six and twelve stories are chosen for this study as shown in Figure 2, building's layout is essentially bi-symmetric in plan, and regular plans of four equal bays with a typical bay width of $5 \mathrm{~m}$ in both directions, and is representative of benchmark typical buildings in current practice in Egypt. The height of every story (column height) is taken equal to $3 \mathrm{~m}$, as a normal height for residential buildings. Beams are assumed on all grid lines.The building structural elements have been first designed according to Egyptian code of practice (ECP203: 2004, 2007; ECP-201: 2008) under static loads assuming an un-cracked sections for beam and slabs in the analysis. Slab thickness was taken $15 \mathrm{~cm}$ and beam section was taken $30 \times 60 \mathrm{~cm}$. These sections have been checked under seismic actions by using the Egyptian code for load and forces (ECP-201: 2008) to satisfy the Egyptian code requirements taking into consideration the effect of earthquake loads. The minimum safe column cross-section under static and dynamic loads, to satisfy the Egyptian code requirements (ECP-203: 2004, 2007; ECP-201: 2008), is $0.6 \times 0.6 \mathrm{~m}$ for 6 -story building and $0.8 \times 0.8 \mathrm{~m}$ for 12 -story building. The ma- 
terials used in the design are C250 for concrete and St52 for steel, the material for the building structure is taken as a reinforced concrete with constant properties of modulus of elasticity $E=2.21 \times 10^{6} \mathrm{t} / \mathrm{m}^{2}$, Poisson ratio $\mu=0.2$, density of concrete $=2.5 \mathrm{t} / \mathrm{m}^{3}$, compressive strength $f_{c}=2500 \mathrm{t} / \mathrm{m}^{2}$, yield strength $f_{y}=36000 \mathrm{t} / \mathrm{m}^{2}$. For gravity load design, dead loads include the self-weight of the structure, a typical floor cover of $0.15 \mathrm{t} / \mathrm{m}^{2}$ and partition (wall) loads intensity of $1.0 \mathrm{t} / \mathrm{m}^{2}$ on all beams including plastering and assuming typical walls thickness of $0.25 \mathrm{~m}$. The model is assumed to be a residential building with live load $=$ $0.2 \mathrm{t} / \mathrm{m}^{2}$.

\subsection{Raft foundation and underneath soil conditions}

For understanding the importance of effect of soil structure interaction on the seismic response of multi-story buildings, this study attention focuses on evaluation the seismic response of reinforced concrete multi-story buildings on raft foundation with thickness equal to $0.6 \mathrm{~m}$ for 6 -story building and $1.0 \mathrm{~m}$ for 12-story building. The underneath soil is modeled by Winkler spring approach with equivalent static stiffness based on soil modulus of elasticity ofrange from 24480, 12240 and $6120 \mathrm{t} / \mathrm{m}^{2}$ for stiff, medium and soft soil (ASTM 1985). The soil spring stiffness can be given as (Gazetas 1991; Mylonakis et al. 2006; Kalkan, Chopra 2010).

$$
\begin{gathered}
K_{z}=\frac{G l}{1-v}\left[0.73+1.54\left(\frac{B}{L}\right)^{0.75}\right] ; \\
K_{y}=\frac{G L}{2-v}\left[2+2.5\left(\frac{B}{L}\right)^{0.85}\right] ; \\
K_{x}=K_{y}-\frac{0.2}{0.75-v} G L\left(1-\frac{B}{L}\right) ; \\
G=\frac{E}{2(1+v)},
\end{gathered}
$$

where, $G$ is shear modulus of soil, $E$ is the modulus of elasticity of soil; $v$ is the Poisson's ratio of soil. $L$ and $B$ are the length and width of foundation, respectively. The elastic properties and stiffness of soil spring for stiff, medium and soft soil are tabulated in Table 1.

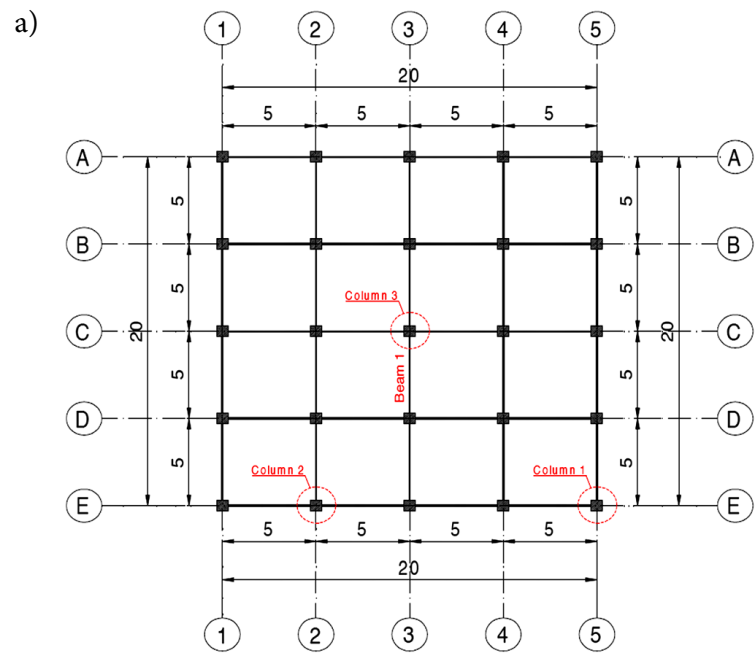

b)

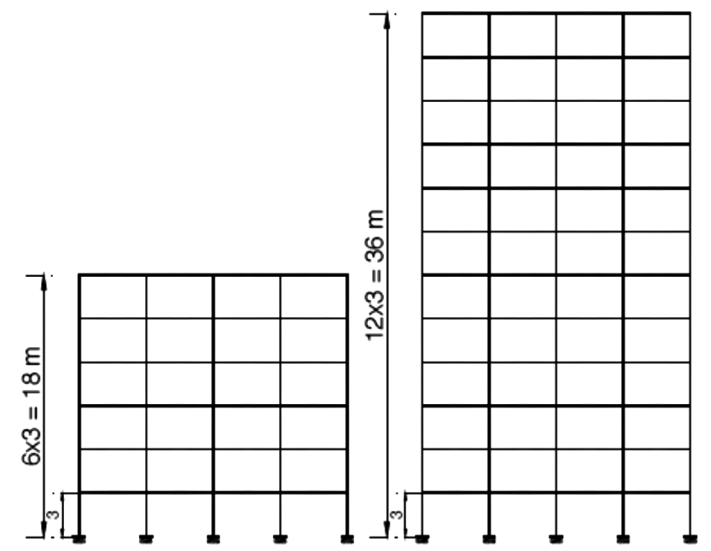

c)

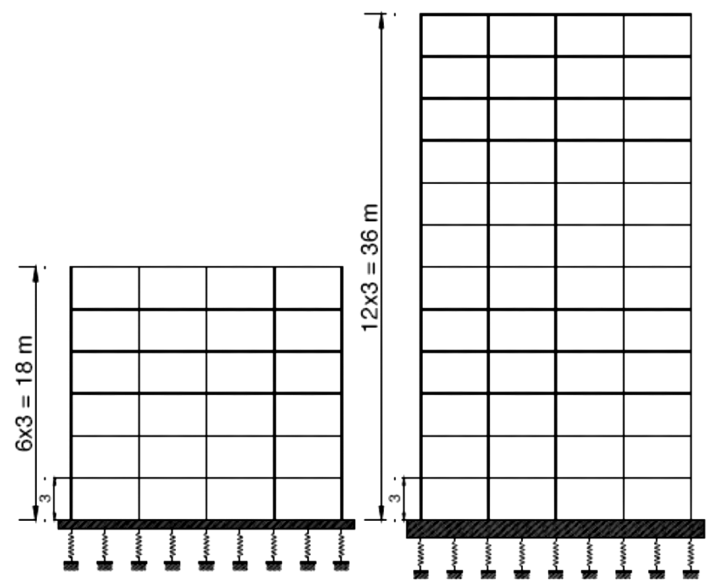

Fig. 2. Configuration of 6-story and 12-story buildings models: a) plan configuration, b) Elevation of fixed base model "NSSI model", c) Elevation of Soil Structure Interaction model"SSI model"

Table 1. Elastic Properties and stiffness of soil area spring element.

\begin{tabular}{|c|c|c|c|c|c|}
\hline Soil condition & $\begin{array}{c}\text { Poisson's ratio } \\
v\end{array}$ & $\begin{array}{c}\text { Modulus of elasticity } \\
E\left(t / \mathrm{m}^{2}\right)\end{array}$ & $\begin{array}{c}K_{x} \\
\left(t / \mathrm{m}^{2} / \mathrm{m}\right)\end{array}$ & $\begin{array}{c}K_{y} \\
\left(t / \mathrm{m}^{2} / \mathrm{m}\right)\end{array}$ & $\begin{array}{c}K_{z} \\
\left(t / \mathrm{m}^{2} / \mathrm{m}\right)\end{array}$ \\
\hline Stiff soil & 0.33 & 24480 & 1127.21 & 1127.21 & 1417.29 \\
\hline Medium soil & 0.33 & 12240 & 563.6 & 563.6 & 708.64 \\
\hline Soft soil & 0.33 & 6120 & 281.8 & 281.8 & 354.32 \\
\hline
\end{tabular}




\subsection{Finite element model}

A three-dimensional mathematical model of the physical structure will be used that represents the spatial distribution of the mass and stiffness of the structure to an extent that is adequate for the calculation of the significant features of the building's dynamic response. All structures are modeled and analyzed in this paper using ETABS 9.7 (CSI 2003, 2011a, 2011b). The building is modeled as $3 \mathrm{D}$ frame structure using frame elements for columns, longitudinal beams and transverse beams, shell element for slabs and raft and spring element for soil.

\subsection{Input seismic excitation}

It is impossible to predict ground motion characteristics that may occur in the future at a construction site because the property of the ground motion is interrelated with many factors such as fault mechanism, seismic wave propagation from source to site and the amplification characteristics of ground. The important factors of ground motions affecting structure's response results are peak ground acceleration, frequency contents, duration of ground motion and shapes of waveform. Egypt is a region of moderate seismicity, where infrequent moderate to large earthquakes have occurred in the past. However, there is a serious lack of strong motion records of engineering interest in the region. Therefore, the use of a large number of artificial or natural earthquake records from the literature is indispensible for the nonlinear time history analysis. The seismic design guidelines provide an acceleration response spectrum for estimating the design seismic force of a structure. Accordingly, the input ground motion applied to the dynamic response analysis of structures would be appropriate for the ground motion history which is highly related with design seismic force. A suite of nine-ground motion records from seven different earthquakes (PEER 2012) is selected for the purpose of understanding the input ground motion effect, as listed in Table 2.

A suite of nine-ground motion acceleration time history records, representing a wide range of intensity and frequency contents, are selected and used in the study. Those records are downloaded from the website of the Pacific Earthquake Engineering Research Center (PEER 2012). The earthquakes records are listed in Table 2 by their magnitude, peak ground acceleration (PGA), peak ground velocity (PGV) and peak ground displacement (PGD). Figure 3 shows the elastic pseudo-acceleration response spectra of the earthquake motions for 5\% damping; the plot shows significant variation in the frequency contents and the response characteristics. The ground motion records

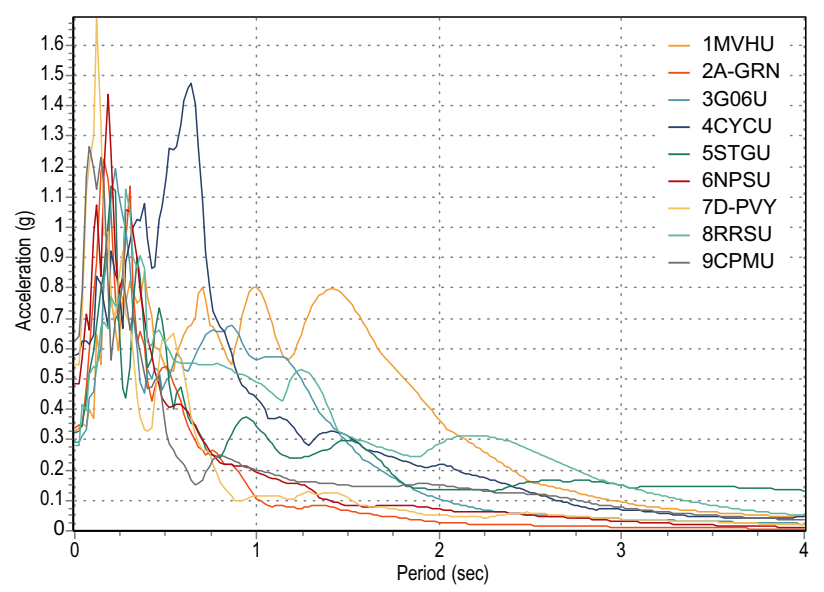

Fig. 3. Associated 5\%-damped response spectrum for nine records

Table 2. Characteristics of earthquake ground motion recordsused in the analysis

\begin{tabular}{|c|c|c|c|c|c|c|c|c|c|}
\hline অ & $\begin{array}{c}\text { PGA } \\
(\mathrm{g})\end{array}$ & $\begin{array}{l}\text { Input } \\
\text { wave }\end{array}$ & $M_{w}$ & Earthquake / Station & $\begin{array}{l}\text { Scale } \\
\text { factor }\end{array}$ & $\begin{array}{l}\text { EPD } \\
(\mathrm{km})\end{array}$ & $\begin{array}{l}\text { PGV } \\
(\mathrm{cm} / \mathrm{s})\end{array}$ & $\begin{array}{l}\text { PGD } \\
(\mathrm{cm})\end{array}$ & $\begin{array}{l}T_{g} \\
(\mathrm{~s})\end{array}$ \\
\hline \multirow{3}{*}{ 范 } & 0.21 & $1 \mathrm{MVH}$ & 6.0 & N. Palm Springs, 1986 / Morongo Valley & 1.5 & 10.1 & 40.9 & 15.0 & 1.90 \\
\hline & 0.30 & 2A-GRN & 6.0 & Whittier narrows, 1987 / E-Grand Ave & 1.7 & 9.0 & 23.0 & 3.3 & 0.70 \\
\hline & 0.29 & 3G06 & 6.2 & Morgan Hill, 1994 / Gilroy Array \#6 & 1.0 & 11.8 & 36.7 & 6.1 & 1.20 \\
\hline \multirow{3}{*}{ 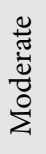 } & 0.48 & $4 \mathrm{CYC}$ & 6.9 & Loma Prieta, 1989 / Coyote Lake Dam & 1.2 & 21.8 & 39.7 & 15.2 & 0.65 \\
\hline & 0.51 & 5STG & 6.9 & Loma Prieta, 1989 / Saratoga-Aloha Ave & 1.0 & 11.7 & 41.2 & 16.2 & 1.80 \\
\hline & 0.59 & 6NPS & 6.0 & N. Palm Springs, 1986 / 5070 & 0.7 & 8.2 & 73.3 & 11.5 & 1.10 \\
\hline \multirow{3}{*}{ 茴 } & 0.60 & 7D-PVY & 5.8 & Coalinga, 1983 / Pleasant Valley P.P. & 1.7 & 17.4 & 34.8 & 8.1 & 0.65 \\
\hline & 0.84 & 8RRS & 6.7 & Northridge, 1994 / Rinaldi & 0.6 & 7.1 & 166.1 & 28.8 & 1.05 \\
\hline & 1.04 & 9CPM & 7.1 & Cape Mendocino, 1992 / Cape Mendono & 0.6 & 8.5 & 42.0 & 12.4 & 2.00 \\
\hline
\end{tabular}


are grouped into three levels depending on the peak ground acceleration as, low ( $0.1 \mathrm{~g}$ up to $0.3 \mathrm{~g})$, moderate $(0.4 \mathrm{~g}$ up to $0.6 \mathrm{~g}$ ) and high ( $0.6 \mathrm{~g}$ up to $1.04 \mathrm{~g}$ ). The records are chosen such that the period ratio $\left(T_{1} / T_{g}\right.$ and $T_{2} / T_{g}$; adjacent buildings period over the ground motion characteristic period) has a wide range.

\section{Numerical results and discussions}

To study the soil-structure interaction; evaluate Egyptian Code seismic provisions; treats the consideration of seismic loads and analysis methods during the seismic design of buildings; to discuss the alternative solutions for cases wherein existing provisions do not lead to satisfactory results and to quantify the effect of Soil-Structure Interaction and foundation flexibility on the structural response so that designers can be aware of the likely impact of their decisions. Time History analysis (TH) has been performed to evaluate Equivalent Static Load (ESL) and the Response Spectrum (RS) analysis methods; a set of time history records has been used. A parametric study is carried out to evaluate the design parameter effects on the building seismic demands in different approaches of analysis and to assess the fundamental period, total base shear, displacements and story drifts for the three methods of analysis, the design parameters includes the SSI with three types of soil and raft thickness. 6-story and 12-story building models with two different system, one of which is system with raft foundation, soil and superstructure (SSI modal for short), and compare with the other one which is over ground portion of building based on -fixed base-rigid foundation hypothesis (NSSI model) have been studied to evaluate the effect of SSI on determination and evaluation of fundamental period, base shear, displacement, story drift, moments at beam ends and inner force of column. A constant beam, slab, columns sections with rigid diaphragm assumption are considered in the analysis with different soil spring stiffness which present in different modulus of elasticity of soil as shown in Table 3. In order to study the soil-structure interaction, fundamental period, base shear, displacement and story drift moments at beam ends, as well as inner force of column in the two models are compared. For convenience, response ratio is defined as below: Response ratio $=$ (peak response of structure in Soil Structure Interaction model) / (peak response of structure in Fixed base model).

\subsection{Natural vibration analysis}

The period of vibration is a fundamental parameter in the force-based design of structures as this parameter defines the spectral acceleration and thus the base shear force to which the building should be designed. This study takes a critical look at the way in which seismic design codes around the world have allowed the designer to estimate the period of vibration for use in both linear static and dynamic analysis. In most building design projects, empirical building period formulas are used to initiate the design process (Kwon, Kim 2010). The fundamental period of vibration, $T$, is a function of the stiffness of the lateral load resisting system and the building mass. The fundamental period in ECP-201 (2008), T, does not influence by the change of SSI but depends only on the building height. Table 4 presents different fundamental periods, for the buildings studied, as obtained from structural analysis using finite element models and empirical expression in ECP-201 (2008) and other international building codes. In both 6 -story and 12-story buildings, the periods computed from empirical expressions are significantly shorter than those computed from structural models especially for building structures with soft soil-

Table 3. Building structural element dimensions for different modulus of elasticity of soil models

\begin{tabular}{|c|c|c|c|c|c|c|}
\hline \multicolumn{2}{|c|}{ Model } & Beam size $(\mathrm{cm})$ & Slab thickness $(\mathrm{cm})$ & Column $(\mathrm{cm})$ & Raft thickness $(\mathrm{cm})$ & Soil modulus of elasticity $\left(t / \mathrm{m}^{2}\right)$ \\
\hline \multirow{4}{*}{$\begin{array}{l}\hat{0} \\
\text { to } \\
b\end{array}$} & NSSI-1 & \multirow{4}{*}{$25 \times 60$} & \multirow{4}{*}{15} & \multirow{4}{*}{$60 \times 60$} & Fixed base & N.A \\
\hline & SSI-1 & & & & 60 & 24480 \\
\hline & SSI-2 & & & & 60 & 12240 \\
\hline & SSI-3 & & & & 60 & 6120 \\
\hline \multirow{4}{*}{$\begin{array}{l}\overrightarrow{0} \\
\stackrel{0}{0} \\
\stackrel{1}{0}\end{array}$} & NSSI-2 & \multirow{4}{*}{$25 \times 60$} & \multirow{4}{*}{15} & \multirow{4}{*}{$80 \times 80$} & Fixed base & N.A \\
\hline & SSI-4 & & & & 100 & 24480 \\
\hline & SSI-5 & & & & 100 & 12240 \\
\hline & SSI-6 & & & & 100 & 6120 \\
\hline
\end{tabular}


spring-stiffness. As the buildings soil-spring-stiffness decrease; the fundamental period increases.Table 4 shows the disparity between the fundamental period of vibration from empirical period-height equation from different codes and the period of vibration from eigenvalue or Rayleigh analysis of a bare frame model. The fundamental period estimated by ECP-201 empirical equation is underestimated especially for flexible models; the fundamental period reaches $183 \%$ and $236 \%$ in models SSI-3 and SSI-6, respectively. Many codes recognize that the period of vibration from the simplified period-height equation is more realistic, having been directly obtained from the measured periods of vibration of buildings subject to earthquake ground motions, but that when higher modes are important (in tall and/or irregular structures) the modal response spectrum method gives a more realistic profile of the lateral forces (Abdel Raheem 2013). However the empirical equation should be calibrated to obtain a conservative estimate for the base shear. As the buildings soilstiffness decrease; fundamental period response ratio increases, fundamental period response ratio is higher than 1.0, rangefrom 1.09 to 1.23 for 6-story model and from 1.12 to 1.36 for 12 -story model as shown in Table 4.

\subsection{Seismic response demands}

\subsubsection{Story drift ratio response}

Story drift ratio is the maximum relative displacement of each floor divided by the height of the same floor is important parameter that has been evaluated. The story drift ratio response demand is investigated for studied multi-story building of 6- and 12-story buildings using different analysis, the story drift ratio over the building's height for different soil condition range from stiff, medium to soft soils along with ratio of the response of the SSI model to that of fixed base model are introduced in Figures 4 and 5 for 6-story building and Figures 6 and 7 for 12 -story building. The seismic response demands are calculated using ESL; RS and average envelope of $\mathrm{TH}$ of the nine records.

Figure $4(\mathrm{a}, \mathrm{b}, \mathrm{c}, \mathrm{d})$ shows that story drift ratio distribution of 6-story model increases gradually and reaches its maximum value in the $2^{\text {nd }}$ story level. The maximum values in NSSI-1, SSI-1, SSI-2 and SSI- 3 using equivalent static load (ESL) method are 0.00081, $0.00089,0.00094$ and 0.00102 respectively. Using response spectra (RS) method are 0.00055, 0.00086, 0.00089 and 0.00095 respectively and the average value of using time history (TH) method of nine earthquake ground motion records are $0.00115,0.00122,0.00122$ and 0.0013 respectively. As the soil stiffness decreases; the story drift ratio increases. The story drift values calculated by TH method have higher values than ESL and RS methods, while those obtained by RS have lower values for story drift.

Figure $5(\mathrm{a}, \mathrm{b}, \mathrm{c})$ shows that story drift ratio response distribution over building height compared to that response value of fixed based model for 6-story model. The story drift ratio increases over the building height as the as the supporting soil change from stiff to soft condition, this increase trend is more significant in the upper and lower stories. The maximum response ratio of SSI-1, SSI-2 and SSI-3 compared to that of fixed base using equivalent static load (SL) method are $1.24,1.39$ and 1.66 respectively, using response spectra method (RS) are 1.74, 1.89 and 2.14 respectively and the average value of using time history method

Table 4. Fundamental period of the RC moment resisting frame building

\begin{tabular}{|c|c|c|c|c|c|c|c|c|c|}
\hline \multirow{2}{*}{ Code } & \multirow{2}{*}{ Period, $T$} & \multicolumn{8}{|c|}{ Fundamental Period (sec) } \\
\hline & & NSSI-1 & SSI-1 & SSI-2 & SSI-3 & NSSI-2 & SSI-4 & SSI-5 & SSI-6 \\
\hline \multicolumn{2}{|c|}{$3 \mathrm{D}$ model natural vibration analysis } & 0.98 & 1.07 & 1.12 & 1.21 & 1.92 & 2.15 & 2.32 & 2.60 \\
\hline \multicolumn{2}{|c|}{ Fundamental period response ratio } & --- & 1.09 & 1.14 & 1.23 & ---- & 1.12 & 1.21 & 1.36 \\
\hline ECP-201 (2008) & $T=0.075 H^{3 / 4}$ & \multicolumn{4}{|c|}{0.66} & \multicolumn{4}{|c|}{1.10} \\
\hline ECP-201 (1993) & $T=0.1 \mathrm{~N}$ & \multicolumn{4}{|c|}{0.61} & \multicolumn{4}{|c|}{1.20} \\
\hline IBC (2003) & $T=0.073 H^{3 / 4}$ & \multicolumn{4}{|c|}{0.65} & \multicolumn{4}{|c|}{1.07} \\
\hline UBC97 (ICBO 1997) & $T=0.049 H^{3 / 4}$ & \multicolumn{4}{|c|}{0.44} & \multicolumn{4}{|c|}{0.74} \\
\hline EC8 (EC 2004) & $T=0.075 H^{3 / 4}$ & \multicolumn{4}{|c|}{0.66} & \multicolumn{4}{|c|}{1.10} \\
\hline NBCC (2005) & $T=0.05 H^{3 / 4}$ & \multicolumn{4}{|c|}{0.44} & \multicolumn{4}{|c|}{0.74} \\
\hline
\end{tabular}

Note: $H$ is the building height above the foundation level and $N$ is the number of the stories. 
a) NSSI-1

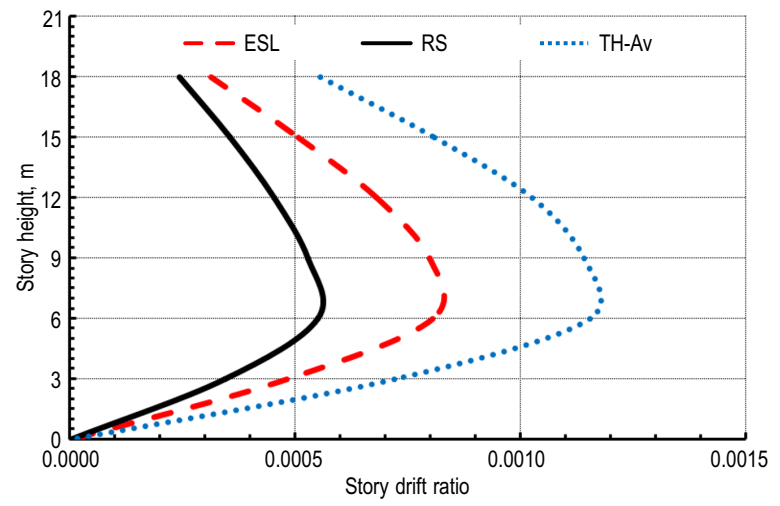

b) SSI-1

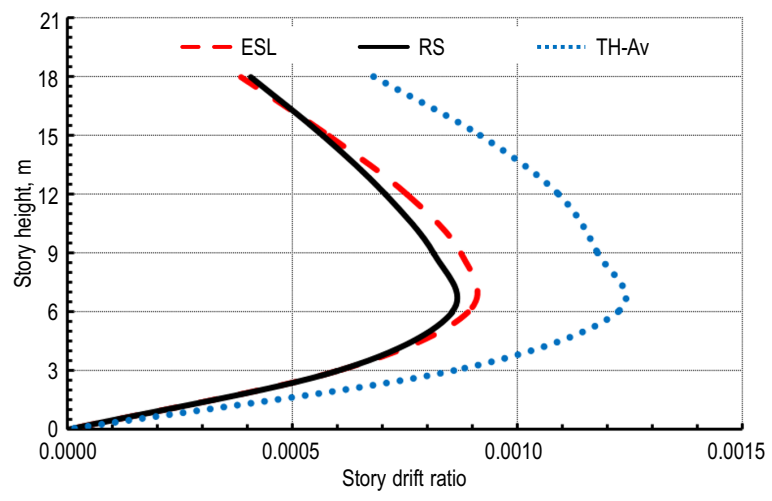

c) SSI-2

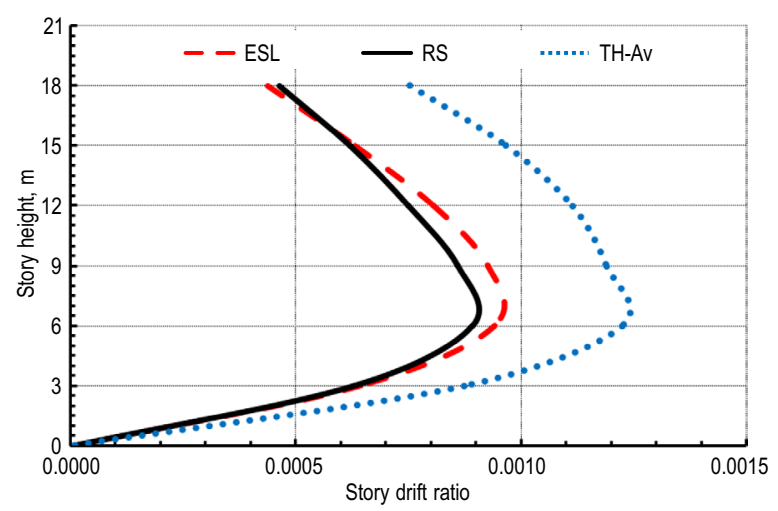

d) SSI-3

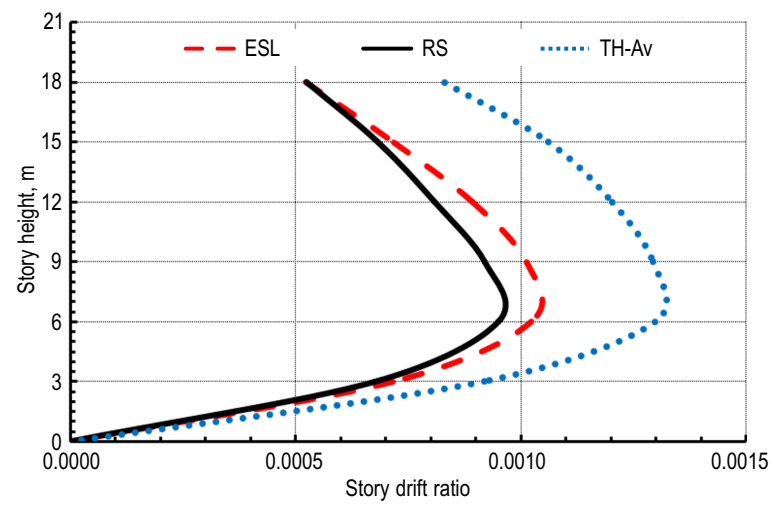

Fig. 4. Story drift ratio of 6-story models
(Av-TH) of nine earthquake ground motion records are $1.22,1.35$ and 1.49 respectively. As the soil stiffness decrease, the story drifts ratio response ratio increase. Lower and upper stories are more affected with SSI than middle stories. As the raft foundation underneath soil flexibly causes the increase of story drift ratio. The greatest story drift ratio increase occurs for the structures located on the soft soil.

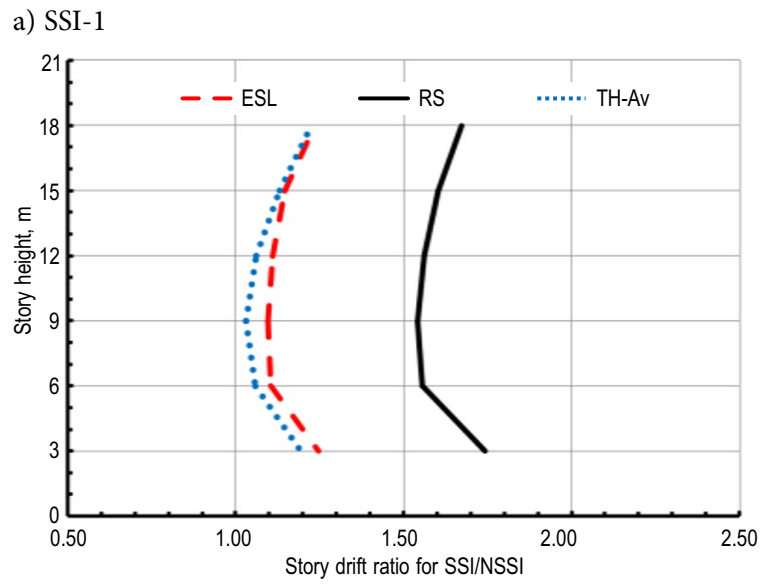

b) SSI-2

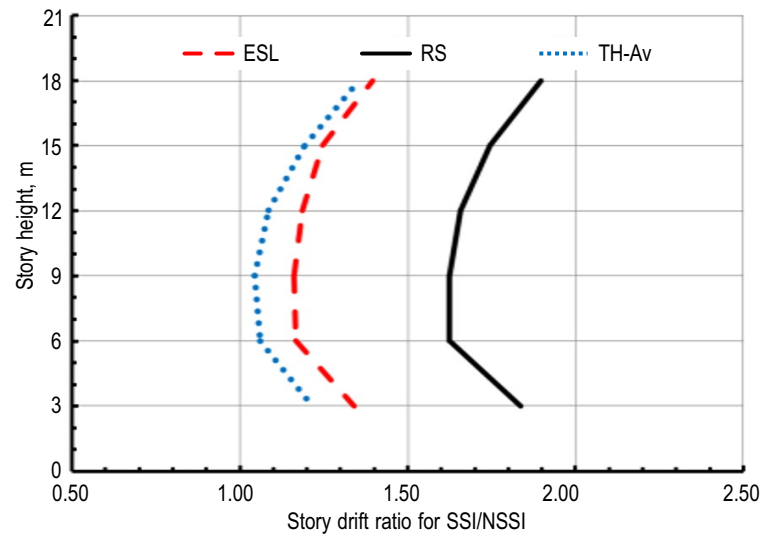

c) SSI-3

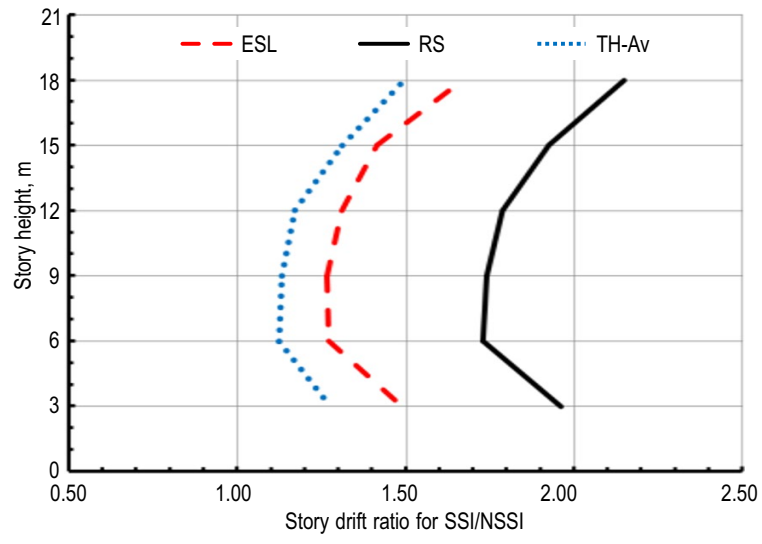

Fig. 5. Story drift ratio of SSI model to that of NSSI model of 6-story models 
Figure $6(a, b, c, d)$ shows that story drift ratio distribution of 12-story model increases gradually and reaches its maximum value in the $3^{\text {rd }}$ and $4^{\text {th }}$ story levels. The maximum values in NSSI-2, SSI-4, SSI-5 and SSI-6 using equivalent static load (ESL) method are $0.00115,0.00134,0.0015$ and 0.00176 respectively. Using response spectra (RS) method are 0.00104, $0.00172,0.00189$ and 0.00218 respectively and the average value of using time history $(\mathrm{TH})$ method of nine earthquake ground motion records are 0.00106 , $0.00111,0.00115$ and 0.00117 respectively. As the soil stiffness decreases; the story drift ratio increases. The story drift values calculated by TH method have higher values than ESL and RS methods, while those obtained by RS have lower values for story drift.

Figure $7(a, b, c)$ shows that story drift ratio response distribution over building height compared to that response value of fixed based model for 12-story model. The story drift ratio increases over the building height as the as the supporting soil change from stiff to soft condition, this increase trend is more significant in the upper and lower stories. The maximum response ratio of SSI-4, SSI-5 and SSI-6 compared to that of fixed base using equivalent static load (SL) method are $1.59,2.06$ and 2.89 respectively, using response spectra method (RS) are 2.09, 2.65 and 3.68 respectively and the average value of using time history method (TH- Av) of nine earthquake ground motion records are $1.4,1.56$ and 1.76 respectively. As the soil stiffness decrease, the story drifts ratio response ratio increase. Lower and upper stories are more affected with SSI than middle stories. As the raft foundation underneath soil flexibly causes the increase of story drift ratio. The greatest story drift ratio increase occurs for the structures located on the soft soil, the SSI gets more significant effect on story drift ratio as the number of story increases.

\subsubsection{Story lateral displacement response}

Soil-structure interaction particularly for MRF buildings resting on relatively soft soils may significantly amplify the lateral displacements and inter-storey drifts. This amplification of lateral deformations may change the performance level of the building frames. Thus, a comprehensive dynamic analysis to evaluate the realistic performance level of a structure should consider effects of SSI in the model. In this study, an enhanced numerical soil-structure model has been developed which treats the behavior of soil and structure a) NSSI-2

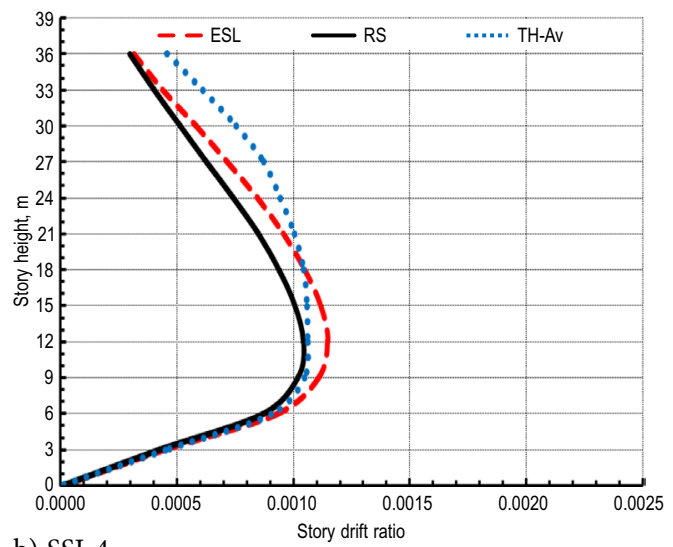

b) SSI-4

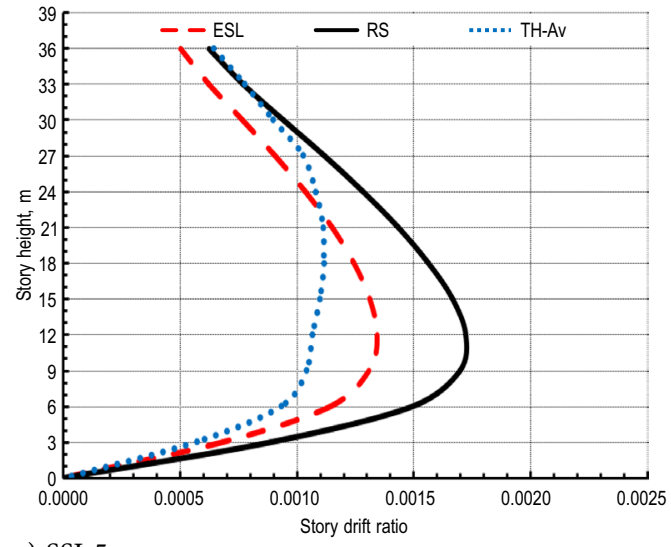

c) SSI-5

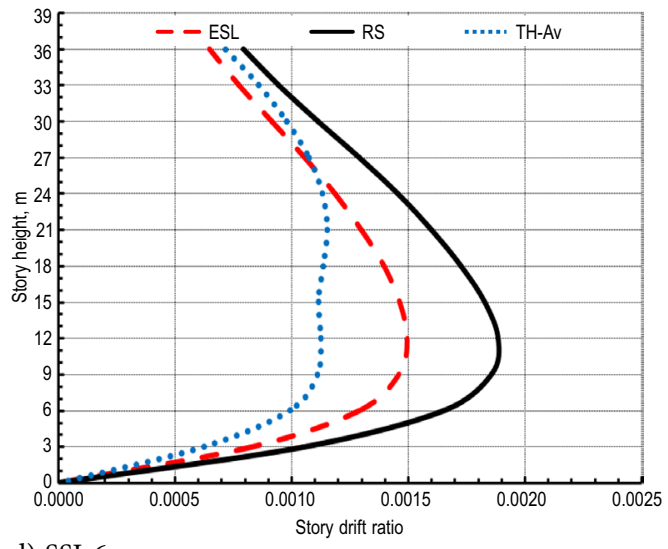

d) SSI-6

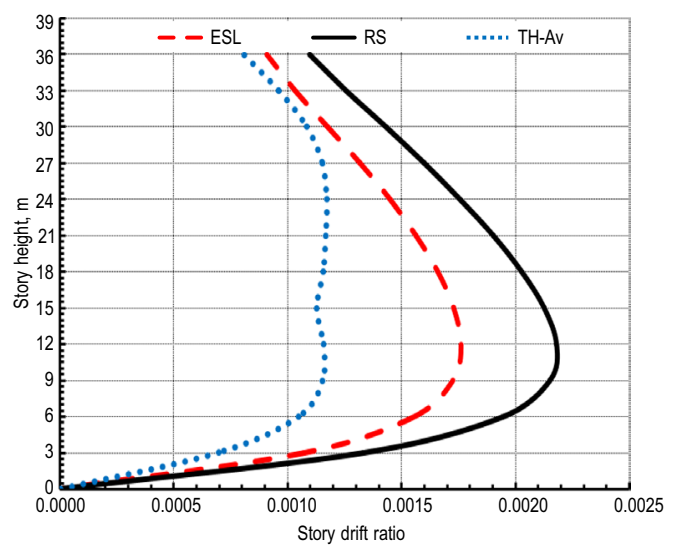

Fig. 6. Story drift ratio of 12-story models 
with equal rigor. In this study, the effect of SSI on the story lateral displacement of 6-story and 12-story buildings have been studied using three different analysis methods, the lateral displacement profile are presented in Figures 8 11. It is observed that the displacement increase occurs in SSI models, the displacement increases more in foundations located on soft soil and this value decreases with increasing soil rigidity.

a) SSI-4

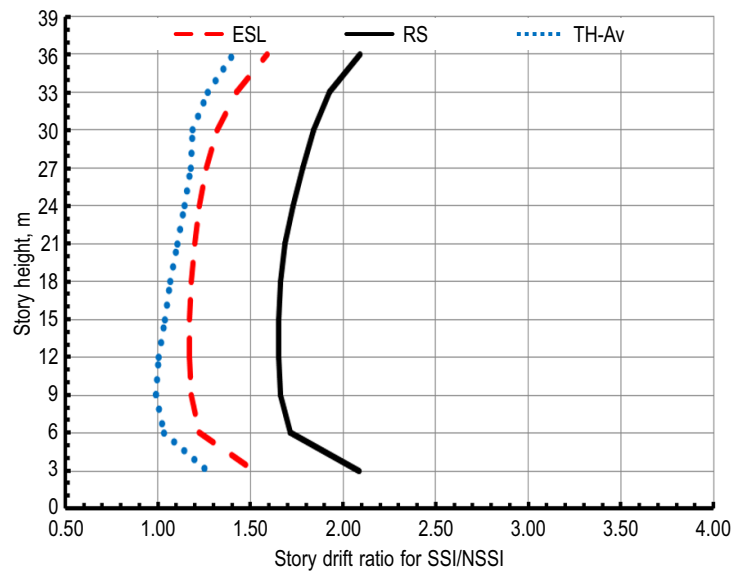

b) SSI-5

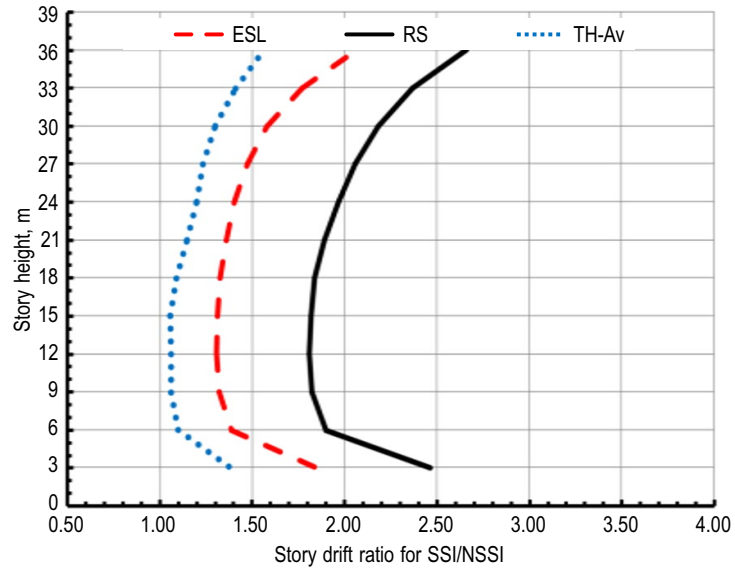

c) SSI-6

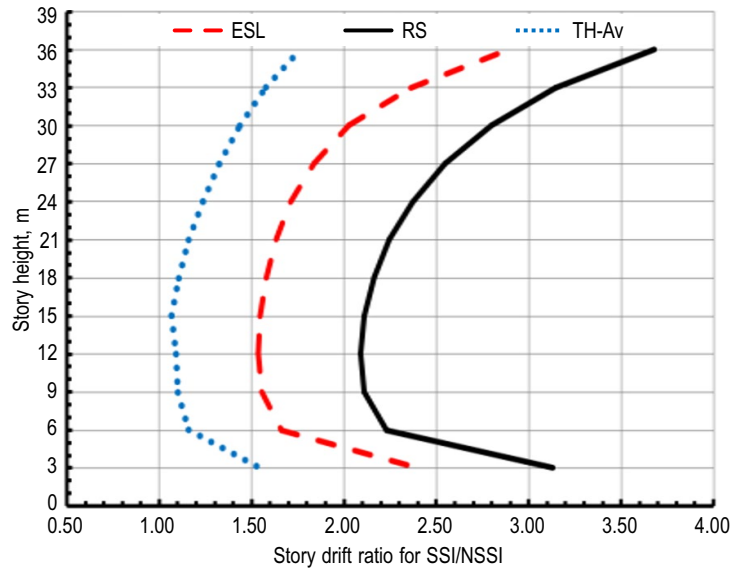

Fig. 7. Story drift ratio of SSI model to that of NSSI model of 12-story models a) NSSI-1

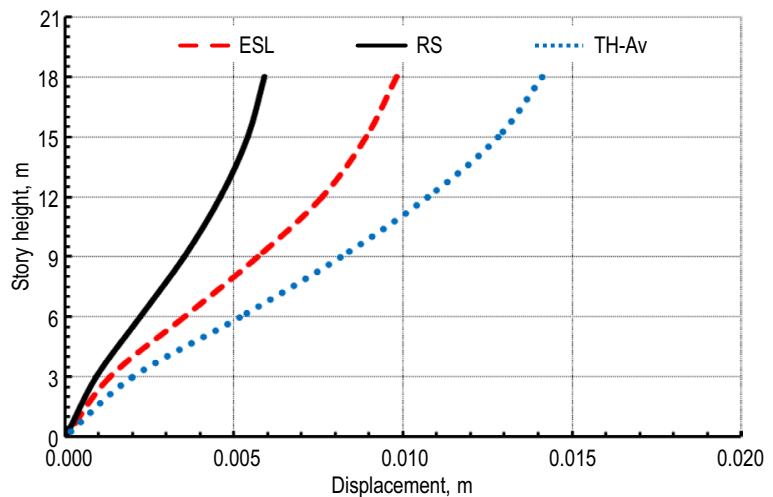

b) SSI-1

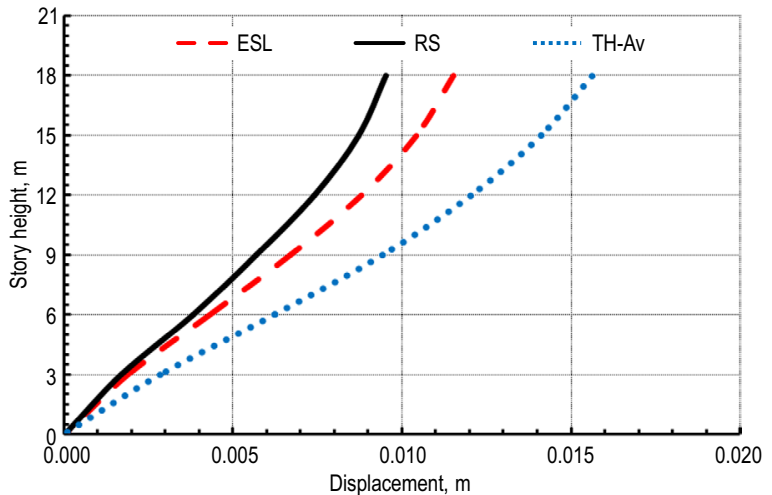

c) SSI-2

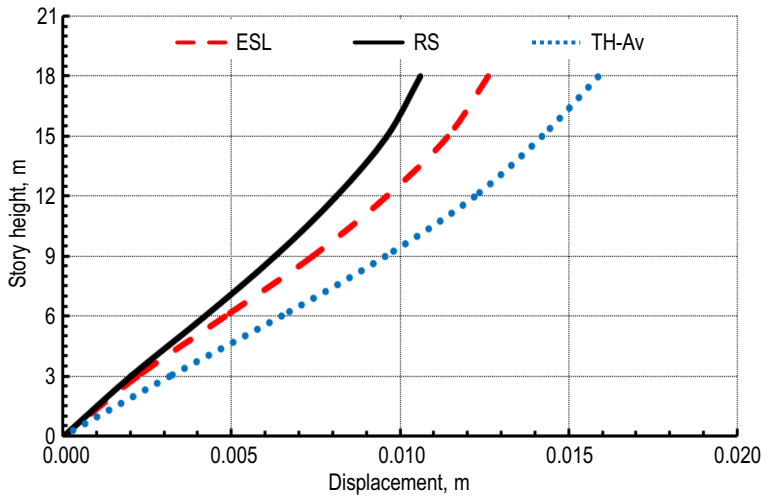

d) SSI-3

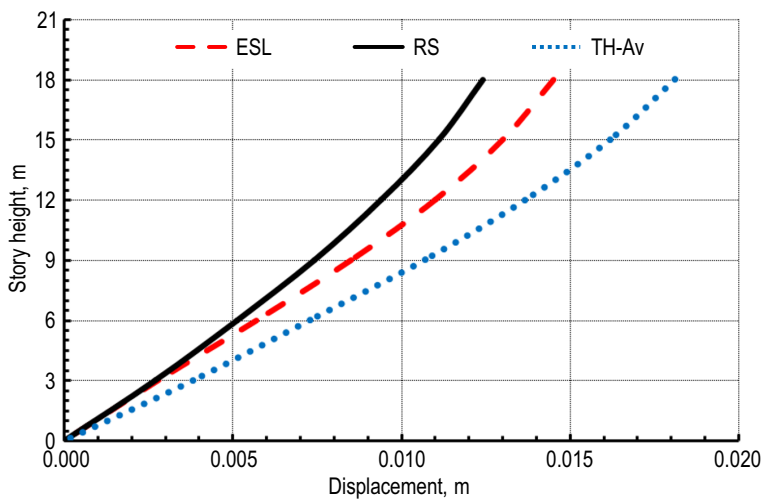

Fig. 8. Story lateral displacements of 6-story models 
Figure 8 (a, b, c, d) shows that story displacement profile over building height of 6-story increasesnonlinearly with the structural height. The maximum displacements reach for NSSI-1, SSI-1, SSI-2 and SSI-3 models using equivalent static load method 9.8, 11.5, 12.6 and $14.5 \mathrm{~mm}$ respectively, using response spectra method reach 5.9, 9.5, 10.6 and $12.4 \mathrm{~mm}$ respectively and using $\mathrm{TH}$, the average value of nine earthquake records reaches 14.11, 15.62, 15.8 and $18.1 \mathrm{~mm}$ respectively. As the soil stiffness decreases, the story displacement increases, Story displacement from TH analysis is higher than ESL and RS analysis.

a) SSI-1

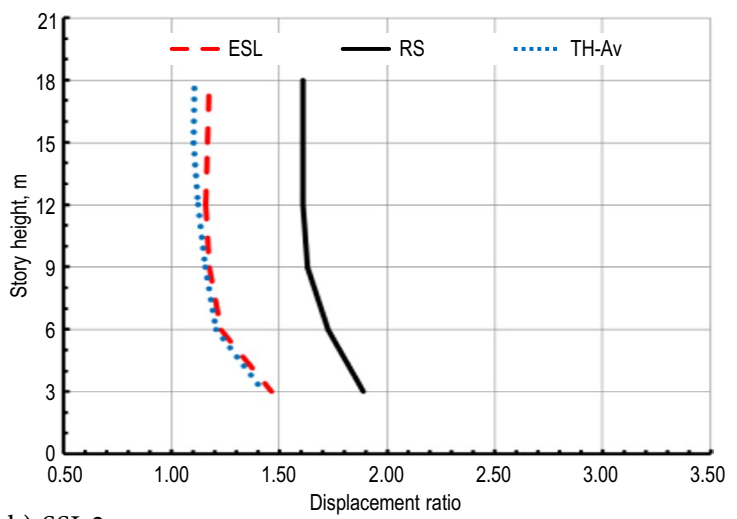

b) SSI-2

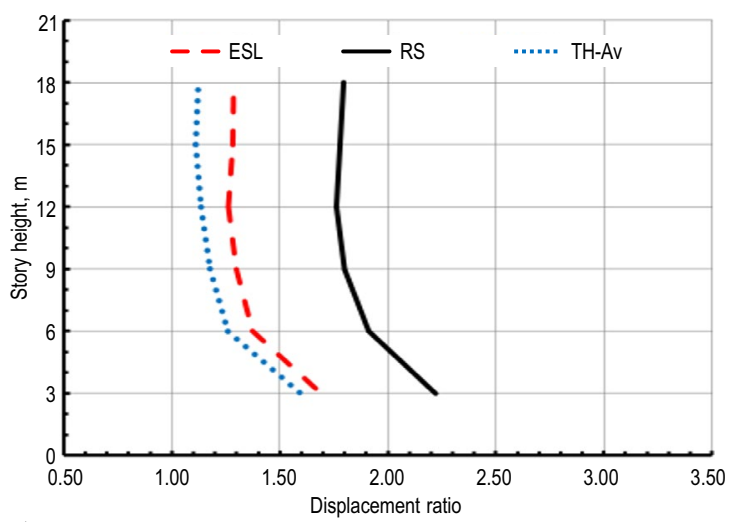

c) SSI-3

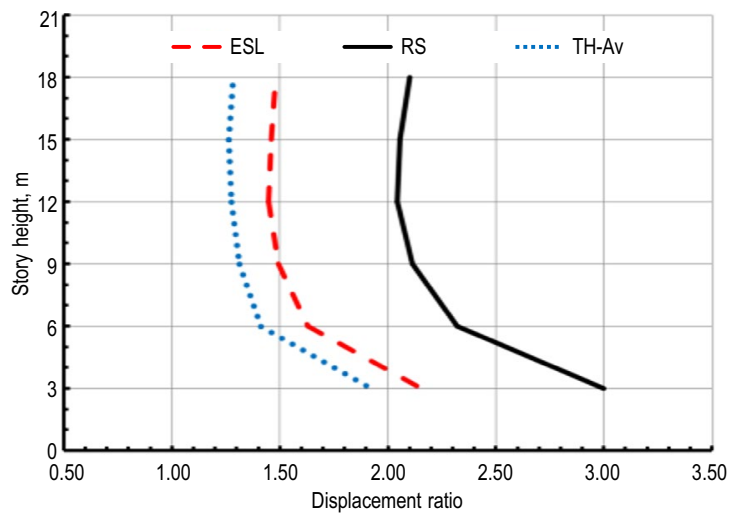

Fig. 9. Story lateral displacement of SSI model to that of NSSI model of 6-story models
Figure $9(a, b, c)$ shows that story displacement response ratio distributions of 6-story SSI models uniformly increase over all stories, the rate of increase become higher for the $1^{\text {st }}$ and $2^{\text {nd }}$ stories. The maximum response ratio of SSI-1, SSI-2 and SSI- 3 using equivalent static load method are 1.46, 1.69 and 2.15 respectively, using response spectra method are 1.88, 2.22 and 3.0 respectively and the average value of using time history method of nine earthquake ground motion records are 1.42, 1.59 and 1.92 respectively. Lower stories are more affected with SSI than the rest stories.

Figure 10 (a, b, c, d) shows that story displacement profile over building height of 12-story increases nonlinearly with the structural height. The maximum displacements reach for NSSI-2, SSI-4, SSI-5 and SSI-6 models using equivalent static load method are 26.5, $33.9,39.6$ and $49.6 \mathrm{~mm}$ respectively, using response spectra method reach 21.6, 39.4, 46.3 and $58.5 \mathrm{~mm}$ respectively and using time history method the average value of nine earthquake records reach 26.1, 27.5, 28.0 and $30.7 \mathrm{~mm}$ respectively. As the soil stiffness decreases, the story displacement increases, Story displacement from TH analysis is higher than ESL and RS analysis.

Figure $11(a, b, c)$ shows that story displacement response ratio distributions of 12-story SSI models uniformly increase over all stories, the rate of increase become higher for the $1^{\text {st }}$ and $2^{\text {nd }}$ stories. The maximum response ratio of SSI-4, SSI- 5 and SSI- 6 using equivalent static load method are 1.83, 2.5 and 3.7 respectively, using response spectra method are 2.7, 3.7 and 5.4 respectively and the average value of using time history method of nine earthquake ground motion records are 1.47, 2.0 and 2.74 respectively. Lower stories are more affected with SSI than the other stories. Soil-structure interaction, particularly for MRF buildings with raft foundation resting on relatively soft soils, creates large lateral displacements and interstorey drifts which may change the performance level of the buildings.

\subsubsection{Story shear force response}

This investigation is aimed to better understand the seismic performance of a typical MRF buildings incorporating soil-structure effect. The seismic response of the structure in terms of the story shear as well as, internal forces over the height of the structural elements are selected as response parameters of interest as these are generally considered the most important response parameters in seismic design practice. 
a) NSSI-2

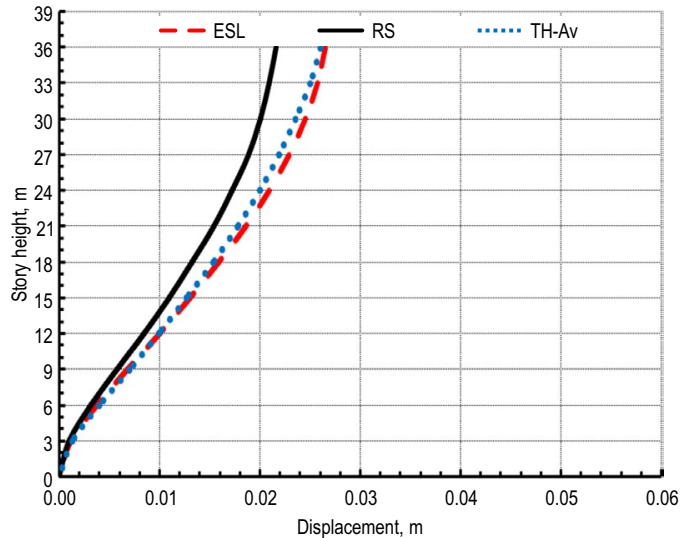

b) SSI-4

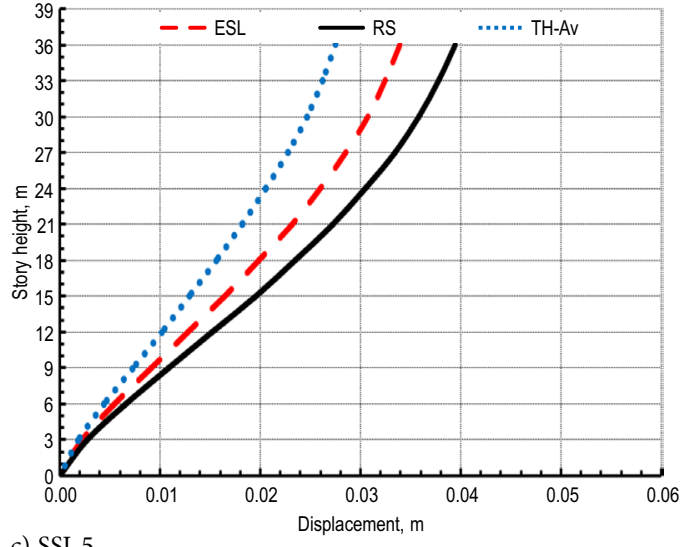

c) SSI-5

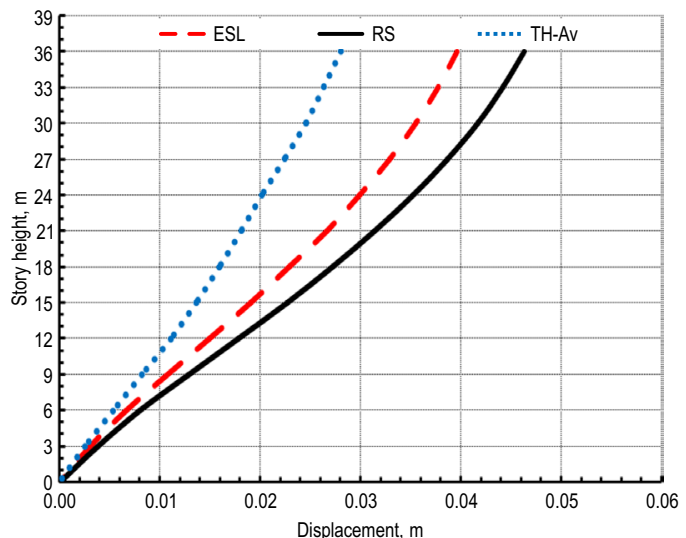

d) SSI-6

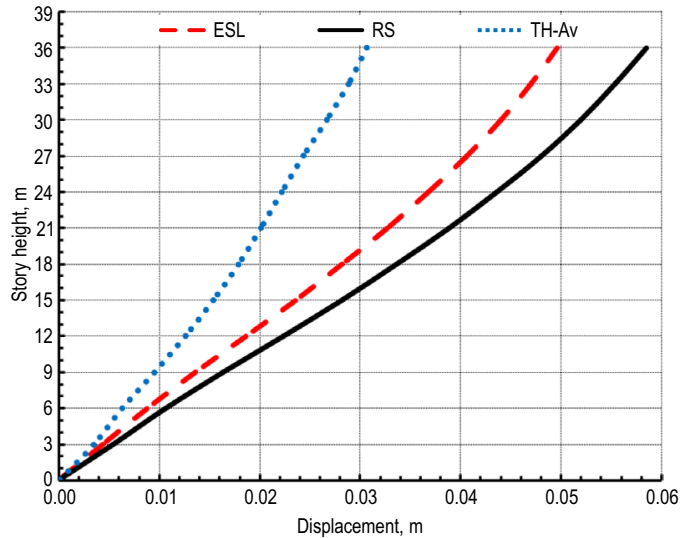

Fig. 10. Story lateral displacements of 12-story models a) SSI-4

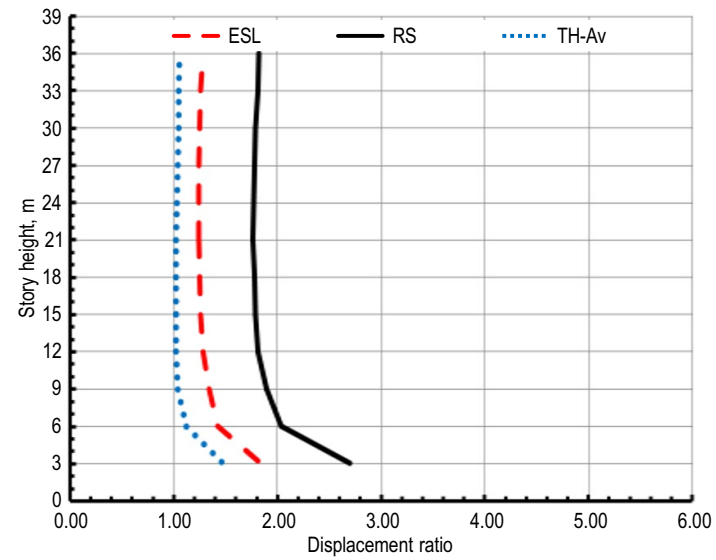

b) SSI-5

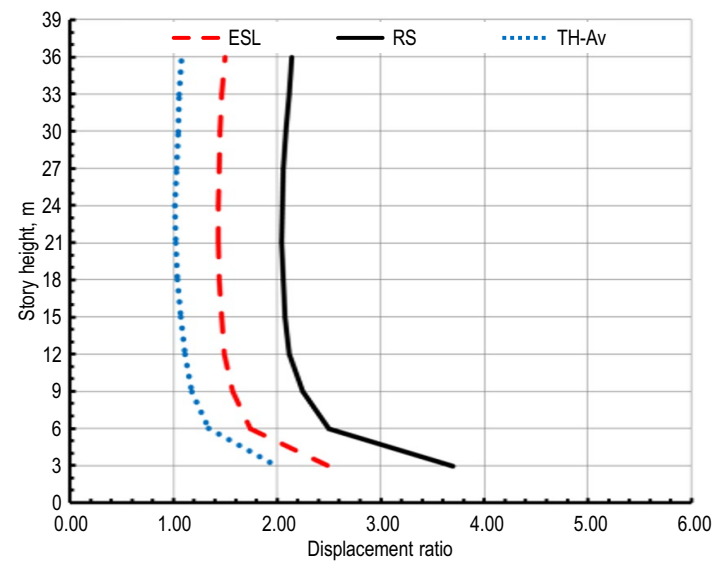

c) SSI-6

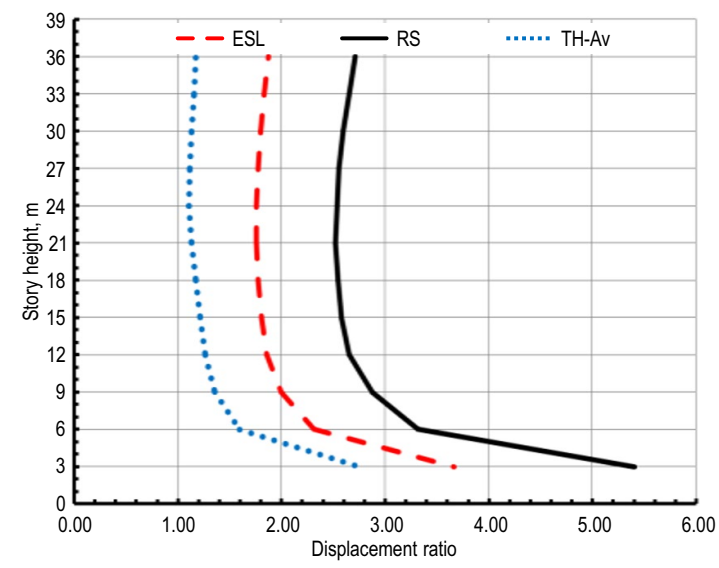

Fig. 11. Story lateral displacement of SSI model to that of NSSI model of 12-story models

The effect of SSI on the story shear response profile over height for 6- and 12-story buildings have been calculated using the three different analysis methods and compared to those obtained from fixed base model. The effect variation of change in story shear due to the incorporation of soil-flexibility as compared to the same obtained at fixed-base condition expressed as a ratio of such response of SSI models to that of fixed based model have been plotted in Figures 12 15. 
Figure $12(a, b, c, d)$ shows that story shear response profile over building height of 6-story models. The maximum base shear values for NSSI-1, SSI-1, SSI- 2 and SSI-3 models using equivalent static load method are constant value of $121.64 \mathrm{t}$. Using response spectra method are $82.5 \mathrm{t}, 116.39 \mathrm{t}, 118.73 \mathrm{t}$ and $117.18 \mathrm{t}$ respectively and using time history method the average value of nine earthquake ground motion records are $198.62 \mathrm{t}, 190.78 \mathrm{t}, 180.12 \mathrm{t}$ and $178.57 \mathrm{t}$ respectively. For RS analysis, as the soil spring stiffness decrease, the story shears increase. For ESL analysis, story shear is not sensitive to the foundation soil flexibility. For TH analysis, as the soil spring get softer, the story shears decrease. Story shear from TH analysis is higher than ESL and RS analysis.

Figure $13(a, b, c)$ shows story shear response ratio of SSI models compared to that of fixed base model of 6-story buildings. Response ratio of story shear under ESL analysis is equal one for all models. The maximum response ratio of SSI-1, SSI-2 and SSI-3; using response spectra method are $1.53,1.56$ and 1.44 respectively and using time history method; the average value of nine earthquake ground motion records are $1.08,1.09$ and 0.9 respectively.

Figure 14 (a, b, c, d) shows that story shear response profile over building height of 12-story models. The maximum base shear values for NSSI-2, SSI-4, SSI-5 and SSI-6 models using equivalent static load method are constant value of $186.24 \mathrm{t}$. Using response spectra method are 163.9 t, $233.34 \mathrm{t}, 233.81 \mathrm{t}$ and $234.93 \mathrm{t}$ respectively and using time history method the average value of nine earthquake ground motion records are $211.5 \mathrm{t}, 209.46 \mathrm{t}, 196.92 \mathrm{t}$ and $185.41 \mathrm{t}$ respectively. For RS analysis, as the soil spring stiffness decrease, the story shears increase. For ESL analysis, story shear is not sensitive to the foundation soil flexibility. For TH analysis, as the soil spring get softer, the story shears decrease. Story shear from TH analysis is higher than ESL and RS analysis.

Figure 15 (a, b, c) shows story shear response ratio of SSI models compared to that of fixed base model of 12-story buildings. Response ratio of story shear under ESL analysis is equal one for all models. The maximum response ratio of SSI-4, SSI-5 and SSI-6; using response spectra method are 1.53, 1.50 and 1.54 respectively and using time history method; the average value of nine earthquake records are 1.2, 1.17 and 1.23 respectively. a) NSSI-1

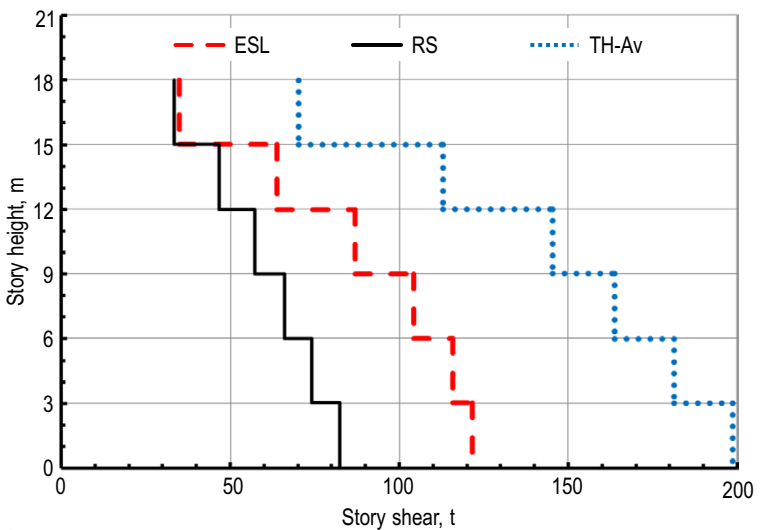

b) SSI-1

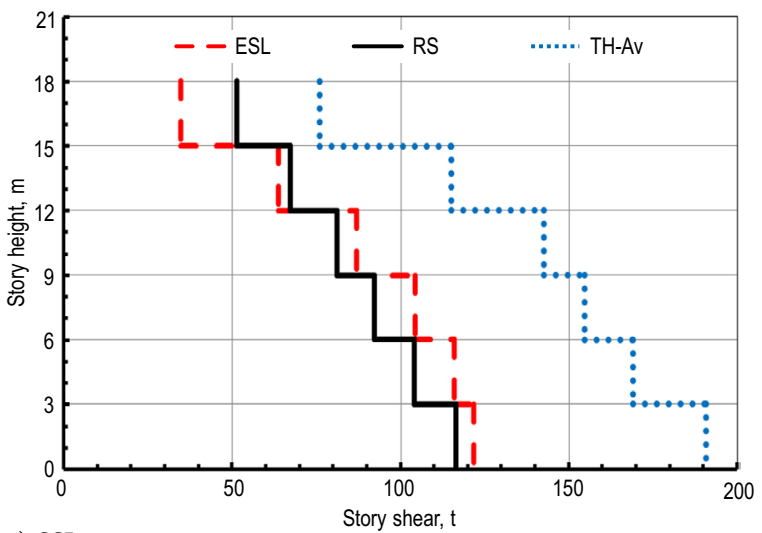

c) SSI-2

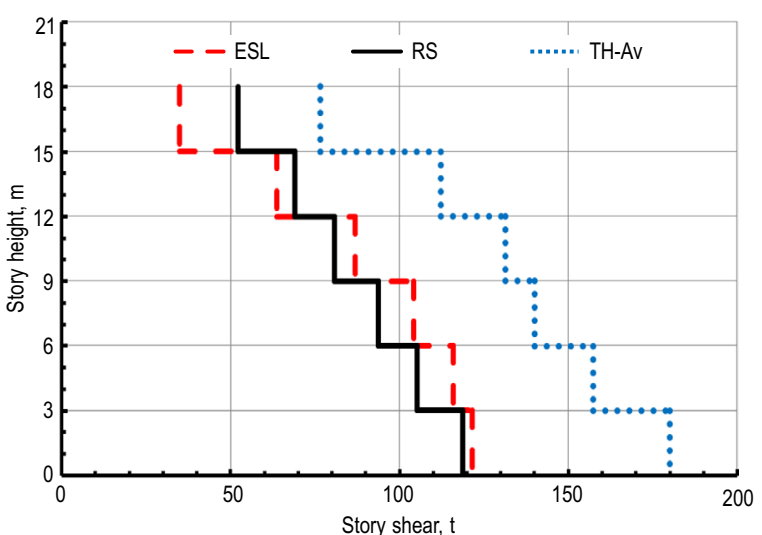

d) SSI-3

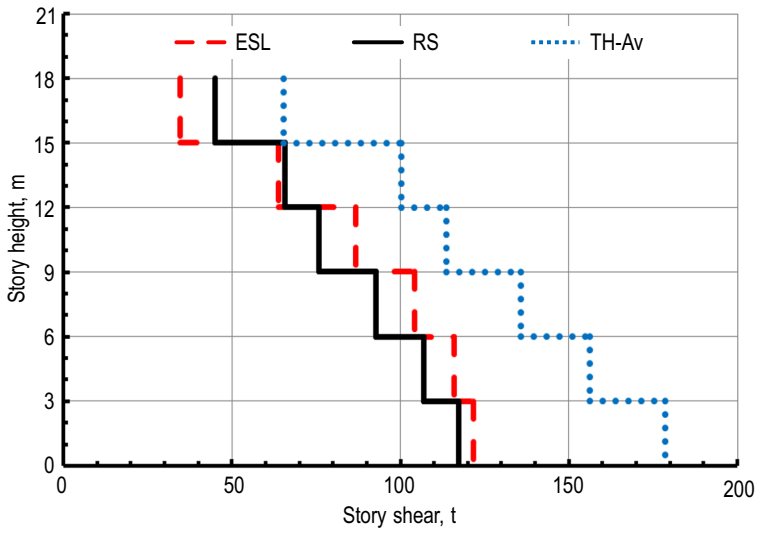

Fig. 12. Story shear force response of 6-story models 
a) SSI-1

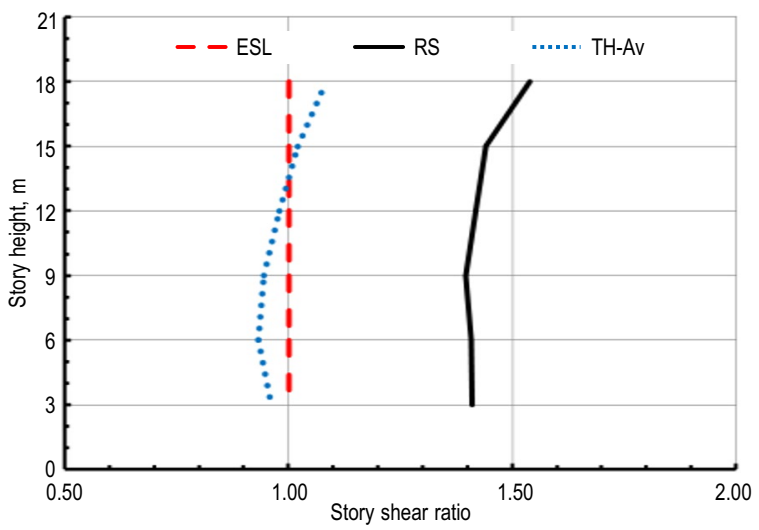

b) SSI-2

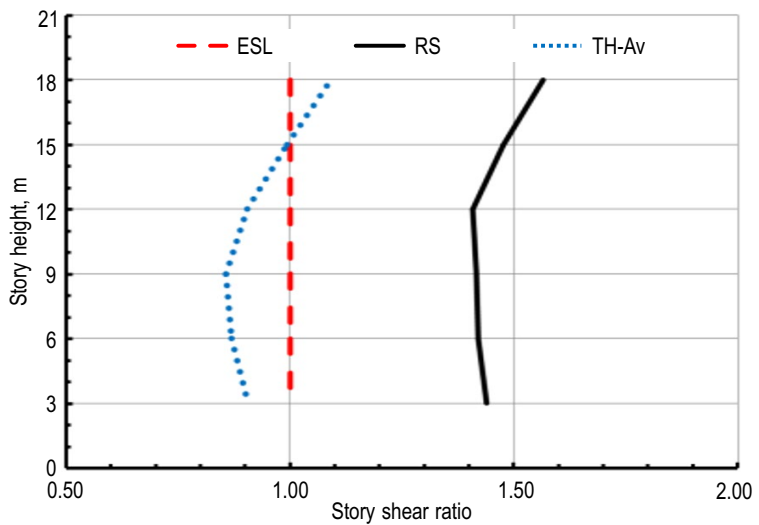

c) SSI-3

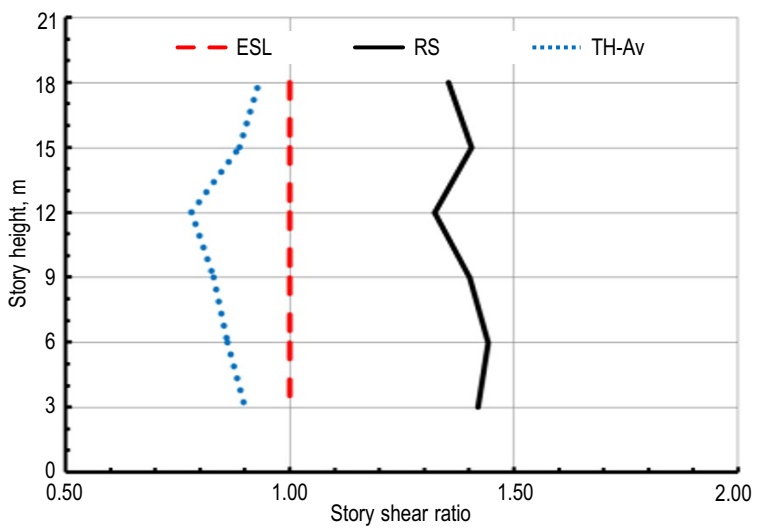

Fig. 13. Story shear force response of SSI model to that of NSSI modelof 6-story models a) NSSI-2

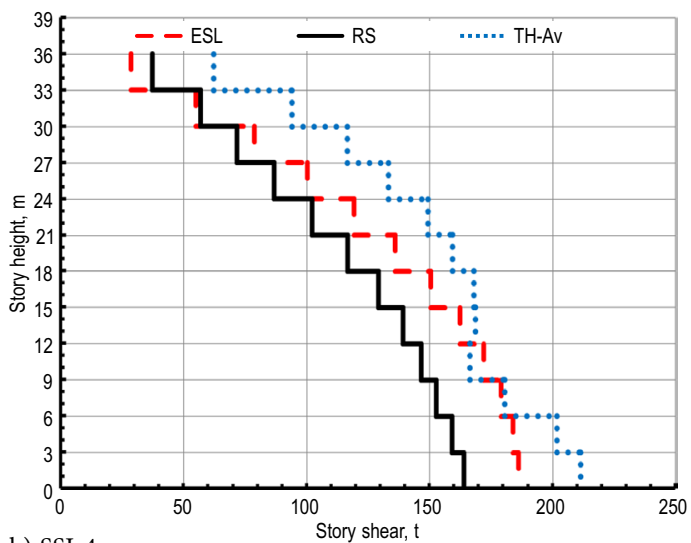

b) SSI-4

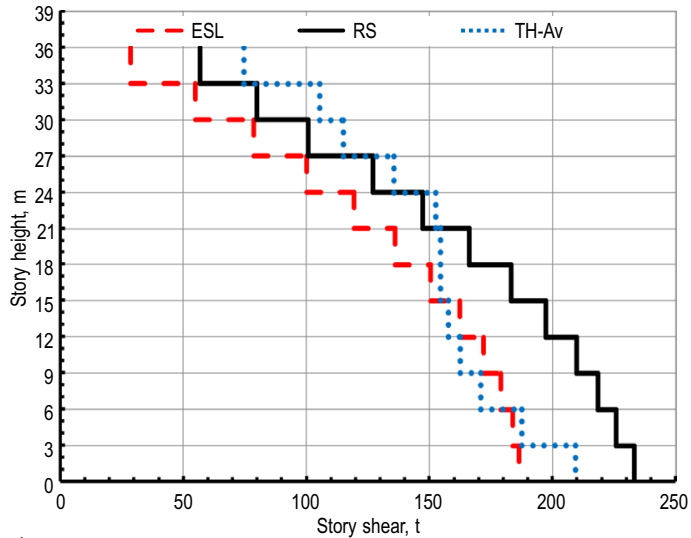

c) SSI-5

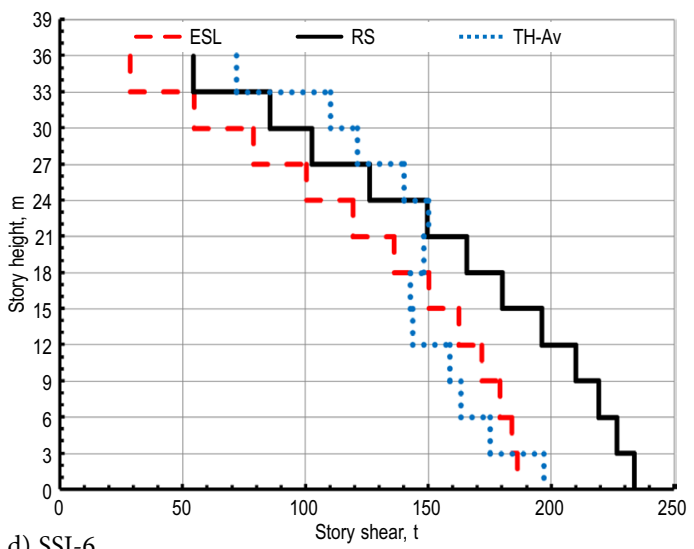

d) SSI-6

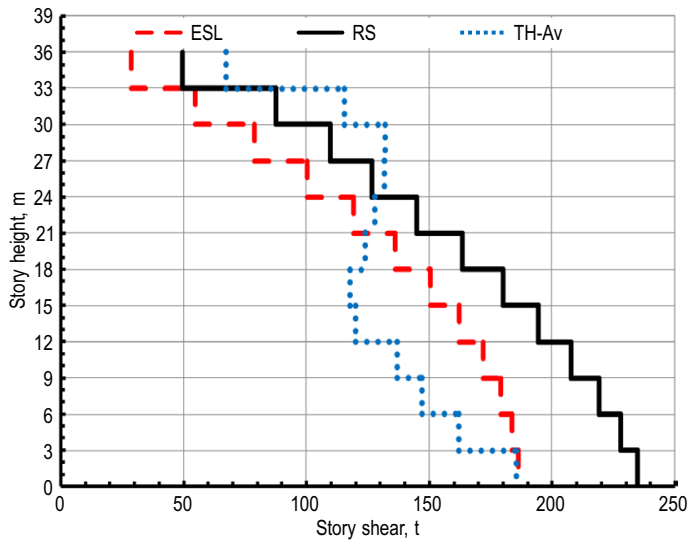

Fig. 14. Story shear force response of 12-story models 
a) SSI-4

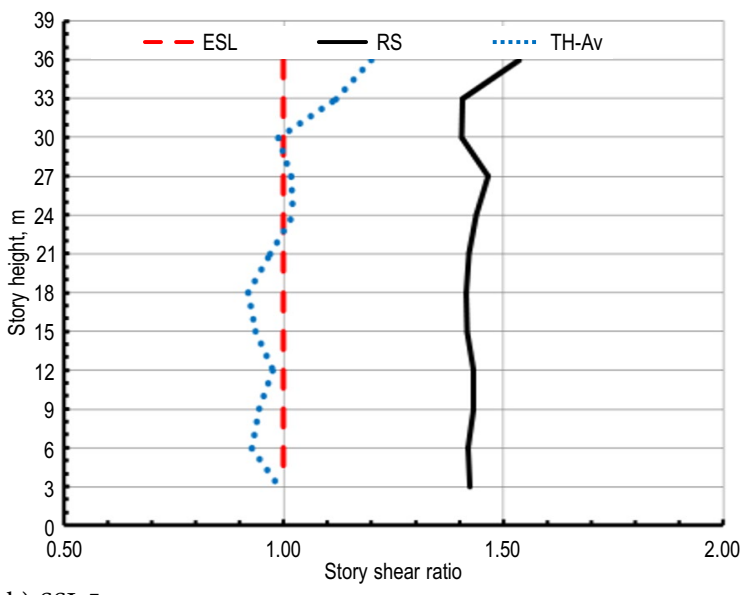

b) SSI-5

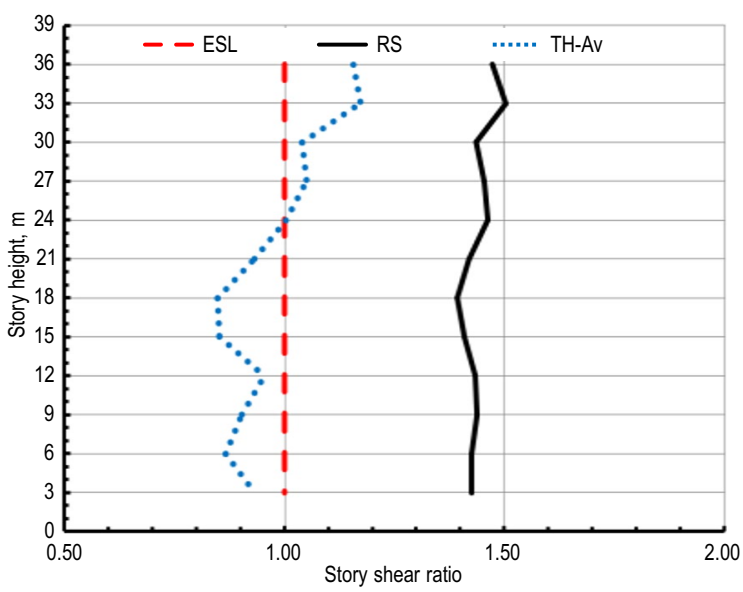

c) SSI- 6

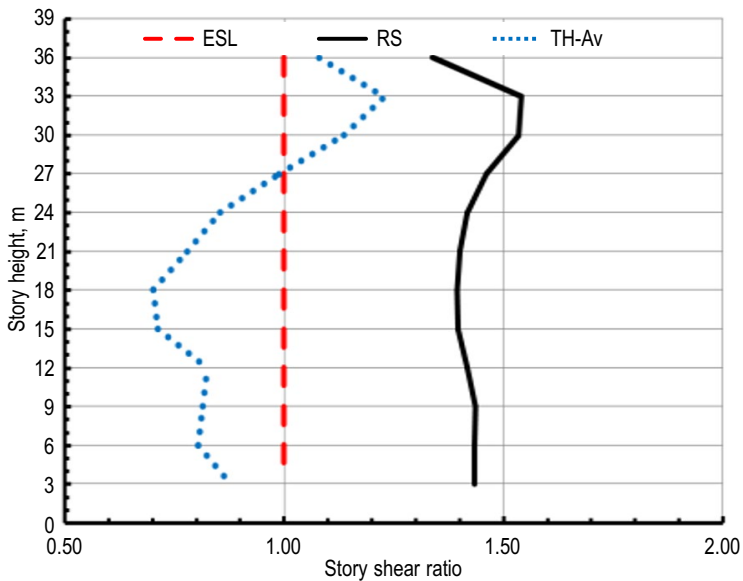

Fig. 15. Story shear force response of SSI model to that of NSSI model of 12-story models

\section{Summary and conclusions}

The study as a whole may prove useful in formulating design guidelines for seismic design of building frames incorporating the effect of soil-flexibility. In this study, the effects of seismic soil-structure interaction are analyzed for typical multi-story building resting on raft foundation, the influences of parameters of slab-column structure-raft foundation-soil model of a practical engineering is carried using three methods of analysis, time history (TH) analysis with a suite of nine time history records, the equivalent static load (ESL) and the response spectrum (RS) methods, which adopted in the Egyptian code for load and forces (ECP-201: 2008). A mathematical model of the complete building-foundation-soil system is developed to determine response quantities not directly available from the records and to ascertain the effects of interaction. The model is calibrated using the dynamic properties of the building as determined from the processed records. The evaluation of SSI is performed through comparison with the results obtained with those from fixed base assumption. The main findings of the study are summarized as follows:

For all models (NSSI and SSI models), the empirical expression for calculating the fundamental period of vibration by ECP-201 (2008) underestimates the fundamental period compared to that models. The structural model is larger than the fundamental period calculated from the ECP-201 (2008) empirical expression. As the soil spring stiffness increases, the fundamental period for the structural model decreases, this means the fundamental period is not only a function of building height but also a function of SSI. The fundamental period calculated from the SSI models are larger than the fundamental period calculated from NSSI models (fixed base models) that means the change in soil stiffness could has significant effect on the fundamental period of vibration. The soil foundation flexibility change affects the seismic demands on the whole structure. Soft soil model displays higher floor displacements compared to that of models of rigid soil/fixed base assumption. The SSI effects are amplified as the number of stories increase. The code empirical methods underestimate the fundamental natural period of structures with SSI. This effect on period calculation means that the design forces are likely to be overestimated, which is conservative.

The story shear response calculated from ESL method is independent from SSI effects and depends only on the building weight. On the contrary, the story shear responses calculated from RS and TH methods are highly dependable upon of the foundation and underneath soil stiffness. Story drift response ratio increases as the soil stiffness deceases. Story drift response ratio increases with increase number of sto- 
ries. Lower and upper stories are more affected with SSI than the middle stories; this effect is amplified as the soil stiffness decreases. The story displacement response increasesas the soil stiffness decease. Story displacement response ratio increases with increase number of stories. Lower stories displacements are more affected with SSI than the rest stories.

The model is then used to evaluate the effects of soil-structure interaction on the maximum base shear force, overturning moment and displacement for the MRF multi-story buildings. The analysis demonstrates that soil-structure interaction has a significant effect on the base forces and roof displacement of the building compared to the typical assumption in which interaction would be neglected. When the ground is stiff enough, the dynamic response of the structure will not be influenced significantly by the soil properties during the earthquake, and the structure can be analyzed under the fixed base condition. When the structure is resting on a flexible medium, the dynamic response of the structure will be different from the fixed base condition owing to the interaction between the soil and the structure. It is concluded that the dynamic soil-structure interaction plays a considerable role in seismic behavior of mid-rise building frames including substantial increase in the lateral deflections and interstorey drifts and changing the performance level of the structures. Thus, considering soil-structure interaction effects in the seismic design of mid-rise moment resisting building frames, particularly when resting on soft soil deposit, is essential. If SSI is not taken into account in analysis and design properly; the accuracy in assessing the structural safety, facing earthquakes, could not be reliable. The conventional design procedures excluding SSI may not be adequate to guarantee the structural safety of regular mid-rise moment resisting building frames resting on soft soil deposits.

\section{References}

Abdel Raheem, K. A.; Abdel Raheem, S. E.; Soghair, H. M.; Ahmed, M. H. 2010. Evaluation of seismic performance of multistory buildings designed according to Egyptian code, Journal of Engineering Sciences, Assiut University 38(2): 381-402.

Abdel Raheem, S. E. 2013. Evaluation of Egyptian code provisions for seismic design of moment resisting frames multistory buildings, International Journal of Advanced Structural Engineering 5(20): 1-18. http://dx.doi.org/10.1186/2008-6695-5-20

Abdel Raheem, S. E.; Ahmed, M. M.; Alazrak, T. M. A. 2014. Soil-structure interaction effects on seismic response of multi-story buildings on raft foundation, Journal of Engineering Sciences, Assiut University 42(4): 905-930.

Algreane, G. A.; Osman, S. A.; Karim, O. K.; Kasa, A. 2011. Behavior of elevated concrete water tank subjected to artificial ground motion, Electronic Journal of Geotechnical Engineering - EJGE 16(Bund D): 386-406.

American Concrete Institute (ASCE). 2005. Building code requirements for structural concrete (ASCE318-05) and Commentary (ASCE318R-05). American Concrete Institute, Farmington Hills, MI, USA.

American Society for Testing and Materials (ASTM). 1985. Classification of soils for engineering purposes: annual book of ASTM standards, D 2487-83, 04.08, American Society for Testing and Materials, 395-408.

Applied Technology Council (ATC). 1978. Tentative provisions for the development of seismic regulations for buildings. Report ATC3-06, Applied Technology Council, Palo Alto, CA.

Applied Technology Council (ATC).1996. Seismic evaluation and retrofit of concrete buildings. Report ATC-40, Applied Technology Council, Redwood City, USA.

Architectural Institute of Japan (AIJ). 1999. Design guidelines for earthquake resistant reinforced concrete structures. Architectural Institute of Japan, Tokyo.

Badawi, H. S.; Mourad, S. A. 1994. Observations from the 12 October 1992 Dahshour earthquake in Egypt, Natural Hazards Journal 10(3): 261-274.

http://dx.doi.org/10.1007/BF00596146

Chopra, A. K. 1995. Dynamics of structures theory and application to earthquake engineering. University of California, Berkeley, USA.

Computers \& Structures Inc (CSI). 2011a. ETABS, Extended three dimensional analysis of building systems. Computer Software Package, Version 9.7.4, Berkeley, CA, USA.

Computers \& Structures Inc (CSI). 2011b. ETABS, Integrated finite element analysis and design of structures. User's manual, CSI, Berkeley, California, USA.

Computers \& Structures Inc (CSI). 2003. ETABS, Integrated building design software, v.9.7. User's manual, CSI, Berkeley, California, USA.

Crowley, H.; Pinho, R. 2010. Revisiting Eurocode 8 formulae for periods of vibration and their employment in linear seismic analysis, Earthquake Engineering and Structural Dynamics 39: 223-235. http://dx.doi.org/10.1002/eqe.949

ECP-201: 1993. Egyptian code for load and force computation in structural works. Housing and Building National Research Center, Ministry of Housing, Utilities and Urban Planning, Cairo, Egypt.

ECP-201: 2008. Egyptian code for calculating loads and forces in structural work and masonry. Housing and Building National Research Center, Ministry of Housing, Utilities and Urban Planning, Cairo, Egypt.

ECP-203: 2004. Egyptian code for design and construction of concrete structures, structural detailing provisions, ECPCS-203. Housing and Building National Research Center, Ministry of Housing, Utilities and Urban Planning, Cairo, Egypt.

ECP-203: 2007. Egyptian code for design and construction of reinforced concrete structures, ECPCS-203. Housing and Building National Research Center, Ministry of Housing, Utilities and Urban Planning, Cairo, Egypt. 
El-Sayed, H. E. 2005. Earthquake nonlinear modeling of R.C building including foundation-soil interaction: Master thesis, Zagazig University, Egypt.

European Committee for Standardization (EC). 2004. Eurocode 8 - Design of Structures for Earthquake Resistance. Part 1: General Rules, Seismic actions and rules for buildings. European Committee for Standardization, EN 1998-1, Brussels, Belgium.

Federal Emergency Management Agency (FEMA). 2000. Prestandard and commentary for the seismic rehabilitation of buildings - FEMA-356. American Society of Civil Engineers (ASCE), Federal Emergency Management Agency, Washington, DC, USA.

Gazetas, G. 1991. Formulas and charts for impedances of surface and embedded foundations, Journal of Geotechnical Engineering 117(9): 1363-1381.

http://dx.doi.org/10.1061/(ASCE)0733-9410(1991)117:9(1363)

Ghosh, S. K.; Fanella, D. A. 2003. Seismic and wind design of concrete buildings: IBC2000, ASCE 7-98, ACI 318-99. 3rd ed. Kaplan Publishing. ISBN-13 9781580011129.

Goel, R. K.; Chopra, A. K. 1997. Period formulas for momentresisting frame buildings, Journal of Structural Engineering 123(11):1454-1461.

http://dx.doi.org/10.1061/(ASCE)0733-9445(1997)123:11(1454)

$\mathrm{Gu}$, Q. 2008. Finite element response sensitivity and reliability analysis of soil-foundation-structure-interaction (SFSI) systems. University of California, San Diego.

International Building Code (IBC). 2003. International Building Code International Code Council. West Flossmoor Road, Country Club Hills, USA.

International Conference of Building Officials (ICBO). 1997. Uniform Building Code (UBC97): Structural engineering design provisions, vol. 2. International Conference of Building Officials (ICBO), Whittier, California.

Kalkan, E.; Chopra, A. K. 2010. Practical guidelines to select and scale earthquake records for nonlinear response history analysis of structures. U.S. Geological Survey Open-File Report. $113 \mathrm{p}$.

Kharade, A. S.; Kapadiya, S. V.; Belgaonkar, S. L. 2013. Earthquake analysis of tall sky-pod structures by considering the soil structure interaction effect, International Journal of Emerging Technology and Advanced Engineering 3(1): 447-454.

Khater, M. 1992. Reconnaissance report on the Cairo, Egypt earthquake of October 12, 1992, NCEER-92-0033, 52 p.

Kunnath, S. K.; Kalkan, E. 2004. Evaluation of seismic deformation demands using non-linear procedures in multistory steel and concrete moment frames, ISET Journal of Earthquake Technology 41(1): 159-181. Paper No 445.

Kwon, O.; Kim, E. S. 2010. Evaluation of building period formulas for seismic design, Earthquake Engineering and Structural Dynamics 39: 1569-1583. http://dx.doi.org/10.1002/eqe.998

Mourad, S. A.; Elattar, A. G.; Megahid, H. A.; Hosny, A. H.; Elthahaby, K. M.; Riad, S. 2000. Assessment of seismic effects on structures in Egypt and measures for mitigation. An Arabic study for the National Academy for Scientific Research and Technology.

Mylonakis, G.; Nikolaou, S.; Gazetas, G. 2006. Footings under seismic loading: analysis and design issues with emphasis on bridge foundations, Soil Dynamics and Earthquake Engineering 26: 824-853.

http://dx.doi.org/10.1016/j.soildyn.2005.12.005

National Research Council of Canada (NRCC). 2005. National Building Code of Canada - NBCC. $12^{\text {th }}$ ed. Canadian Commission on Building and Fire Codes, National Research Council of Canada, Ottawa, Ont.

Pacific Earthquake Engineering Research Center (PEER). 2012. The Pacific Earthquake Engineering Research Center [online], [cited June 2012]. Strong Motion Database. Available from Internet: http://peer.berkeley.edu/smcat/search.html.

Paz, M.; Leigh, W. E. 2003. Structure dynamics theory and computation. 5th ed. Springer. ISBN 139781402076671.

Structural Engineers Association of California (SEAOC). 1999. Recommended lateral force requirements and commentary. 7th ed. Seismology Committee, Structural Engineers Association of California (SEAOC).

Thuat, D. V. 2014. Strength reduction factor demands for building structures under different seismic levels, The Structural Design of Tall and Special Buildings 23(1): 42-53.

http://dx.doi.org/10.1002/tal.1018

Shehata E. ABDEL RAHEEM. Dr Eng., Prof. of Earthquake, Bridge, Structural and Geotechnical Engineering; 2014, Civil Engineering Department, Faculty of Engineering, Assiut University, Egypt. Doctor of Engineering; 2003 and Japan Society for the Promotion of Science fellow; 2006, Hokkaido University, Japan. Alexander von Humboldt fellow; 2005, Kassel University, Germany. He has published more than 80 papers in the field of structural engineering, structural analysis, earthquake engineering, soil structure interaction, seismic pounding, structural control, and nonlinear dynamic of offshore structures. He is a previous member of the Japan Society of Civil Engineers. He reviewed many papers for international journals. He is currently working as an engineering counselor at the general project management of Taibah University. He is Prof. of Earthquake, Structural and Geotechnical Engineering, Faculty of Engineering, Taibah University, Madinah, Kingdom of Saudi Arabia.

Mohamed M. AHMED. Dr Eng., Associate Professor of reinforced concrete structures 2000, Department of Civil Engineering, Faculty of Engineering, Assiut University. Doctor of Engineering; 1993. He reviewed many papers for international journals. He is Emeritus Associated Professor of Structural Engineering, Faculty of Engineering, Assiut University, Egypt.

Tarek M. A. ALAZRAK. Civil engineer, Faculty of Engineering, Sohag University, Egypt. He awarded B.Sc. in June 2010 with grade "very good with honor degree" and graduated for M.Sc. in 2014 in the field of Earthquake and Structural Engineering field, from the Faculty of Engineering, Assiut University. 